\title{
A Evolução do Direito Português do Ambiente nos Últimos 25 Anos
}

\author{
Pedro Cunha Serra \\ Portugal-aprb@,aprb.pt
}

Artigo convidado. Aprovado em julho.

\begin{abstract}
RESUMO
Nos últimos 25 anos teve lugar em Portugal uma verdadeira revolução em matéria de Direito do Ambiente. Com a consagração constitucional do Ambiente como direito dos cidadãos ocorrida em 1976, deu-se a transmutação do Ambiente de mero interesse em bem jurídico digno de proteçãa. Este facto veio a ter as repercussões mais profundas e deu lugar à criação de um novo ramo do Direito, o Direito do Ambiente. São passados em revista os momentos e os diplomas mais marcantes que ocorreram durante o período em análise e é apreciado o seu significado para os objectivos de proteção visados.
\end{abstract}

Palavras-chave: Portugal; ambiente; legislação.

\section{ADVERTÊNCIA}

Este é um trabalho sobre o Direito do Ambiente da autoria de um não jurista. Atrevemo-nos a tal estimulados pelas palavras de Sousa Franco (1994). Diz este autor que "o que predomina no Direito do Ambiente, que é um Direito do Estado e portanto não tem muito de institucionalização de regras próprias da sociedade, é sobretudo a institucionalização de políticas. Ora, se não entendermos quais são os objectivos dessas políticas, uma das concretizações da função social dos institutos e das normas jurídicas, e o conteúdo das sua estratégias, julgaremos que estamos a estudar Ciência do Direito, mas na realidade estamos apenas a estudar umas normas desgarradas, sem espírito de sistema e sem entender o que elas representam na ordem social." Este texto deve pois ser entendido como o contributo de um técnico da área da engenharia para o diálogo interdisciplinar necessário a uma melhor compreensão das normas do Direito do Ambiente. Aos juristas que a ele venham a dedicar a sua atenção pede desde já o autor que lhe relevem o seu atrevimento por esta incursão pelo mundo do Direito, as interpretações simplistas e porventura erradas de algumas das suas normas e a falta de rigor no tratamento dos conceitos jurídicos.

\section{INTRODUÇÃO}

Nos últimos cerca de 25 anos, que podemos datar mais precisamente da restauração da democracia entre nós, ocorreu uma profunda mudança do quadro legal e institucional para o Ambiente, apenas comparável àquela que teve lugar há sensivelmente um século atrás, aquando da aprovação do Decreto n. ${ }^{\circ}$ 8, de 1 de Dezembro de 1892, que estabeleceu a organização dos Serviços Hidráulicos e o respectivo Regulamento. Tal como há cerca de um século, a reforma da legislação foi acompanhada por uma mudança profunda das instituições da Administração Pública que se ocupam da sua aplicação, naquela altura com a criação dos Serviços Hidráulicos, de âmbito nacional, a partir das circunscrições hidráulicas pré-existentes, agora com a criação de um Ministério do Ambiente e de organismos especializados para os vários componentes ambientais naturais.

A profundidade da reforma operada é-nos dada, desde logo, pelas extensas listas de diplomas aprovados e de diplomas revogados ou derrogados ao longo deste período, sobretudo na última década. A este respeito, e a título meramente indicativo uma vez que não se trata de listas exaustivas, longe disso, vejam-se, para os primeiros, a lista do Anexo II ao Decreto-Lei n. ${ }^{\circ}$ 194/2000, de 21 de Agosto, que transpõe para o Direito português a directiva comunitária sobre o planeamento e o controlo integrados da poluição, com cerca de 40 entradas, a mais antiga das quais de 1987, e para os segundos a lista dos diplomas derrogados pelo Decreto-Lei n. ${ }^{\circ}$ 46/94, de 22 de Fevereiro, relativo ao regime de licenciamento das utilizações do domínio público hídrico, artigo $91^{\circ}$, com 26 entradas, das quais a primeira é precisamente, e não por acaso, o Decreto n. ${ }^{\circ} 8$, de 1 de Dezembro de 1892, com que se havia iniciado a reforma do século anterior.

Como seria expectável, esta reforma teve também expressão constitucional. Desde logo, e já em 1976, quando os direitos ambientais foram inscritos na Constituição da República Portuguesa (CRP) a par dos demais direitos económicos, sociais e culturais cuja efectivação incumbe ao Estado (artigos $9^{\circ}$ e $66^{\circ}$ ). Com a autonomização do Ambiente operada pela Constituição de 1976 dá-se entre nós aquilo que Gomes Canotilho et al. (1998) e Figueiredo Dias (2002) classificam como a transmutação do Ambiente de mero interesse socialmente relevante em bem jurídico e a sua autonomização em relação a outros bens jurídicos dignos de protecção, como a vida, a saúde ou a propriedade das pessoas. Esta transmutação e esta autonomização teriam de ter expressão no Direito, com a criação de um corpo de normas de Direito do Ambiente, autónomo em relação às normas do Direito Administrativo de que pode 
considerar-se um capítulo. O carácter revolucionário deste novo ramo do Direito fica bem expresso pelas palavras de Freitas do Amaral (1994), segundo o qual ele seria "o primeiro ramo do Direito que nasce, não para regular as relações dos homens entre si, mas para tentar disciplinar as relações do Homem com a Natureza".

Entretanto, uma visão mais completa da extensão e profundidade desta reforma exige uma apreciação do enquadramento legal dos novos conceitos que operam neste ramo do saber, o ambiente, e a sua inserção no movimento internacional de que a Conferência da Terra, que se realizou no Rio de Janeiro em 1992, é a expressão mais acabada. No âmbito regional europeu em que nos inserimos, são várias as iniciativas que marcam profundamente a evolução desses conceitos e das soluções legais, mas há que referir o acto fundador da inscrição do Ambiente como política comunitária no Tratado da União Europeia, pelo Acto Único Europeu de 1987, e, no que concerne à água, a aprovação, sob a presidência portuguesa, no primeiro semestre de 2000, e a entrada em vigor no final desse ano, da directiva 2000/60/CE do Parlamento e do Conselho que estabelece um quadro de acção comunitária no domínio da política da água, também conhecida por directivaquadro da água (DQA).

Hoje a UE tem uma política de Ambiente inscrita no seu Tratado fundamental. É o n. ${ }^{\circ} 2$ do seu artigo $174^{\circ}$ (antigo artigo 130r) que determina que a política da Comunidade para o Ambiente deve contribuir para a preservação, a protecção e a melhoria da qualidade do Ambiente e a utilização prudente e racional dos recursos naturais, assim como visar um elevado nível de protecção, e será baseada no princípio da precaução e nos princípios da acção preventiva, da rectificação na fonte e do poluidor-pagador. Esta definição de princípios tem consequências profundas, que importa assinalar, e está a marcar a evolução mais recente do Direito nacional para o sector.

\section{O DIREITO DO AMBIENTE COMO NOVO RAMO DO DIREITO}

A respeito do Direito do Ambiente Gomes Canotilho et al. (1998) colocam a questão: Direito do Ambiente, novo ramo do Direito ou simples pretexto para revisão dos ramos clássicos? Nos seus dizeres, "uma questão que neste momento se pode ainda pôr aos juristas é a de saber se a "abordagem jurídica do Ambiente" constitui apenas uma refracção dos ramos clássicos do Direito neste novo campo ou se, pelo contrário, esse tratamento apresenta novidades significativas, até ao ponto de se poder falar com propriedade num novo ramo do Direito: o Direito do Ambiente".

Tendo em vista o esclarecimento desta questão os autores identificam algumas ideias fundamentais que recompilamos. Em primeiro lugar, a emergência, no mundo do Direito, de um novo valor, o valor Ambiente, "que se projecta num novo bem jurídico colectivo e num novo direito subjectivo". Depois, o contributo que é exigido a todos os ramos clássicos do Direito e os ensinamentos de outras ciências naturais e sociais que têm de ser convocados em vista à formulação das soluções deste ramo do Direito. Ainda, os esquemas jurídicos tradicionais revelarse-iam insuficientes para resolver muitas questões jurídicas ambientais, como consequência da conjugação de diversos factores derivados dos próprios conceitos de ambiente, dano ambiental e responsabilidade pelo dano, entre outros. E questionam as visões antropocêntrica, biocêntrica ou ecocêntrica deste Direito (segundo Figueiredo Dias, 2002, economicocêntrica ainda, na qual a protecção do ambiente tem por base a necessidade de proteger recursos escassos, o que, em nossa opinião, nos reconduziria, no entanto, à visão antropocêntrica). Para sublinharem a enorme dimensão dos problemas do ambiente e a sua especificidade, destacam a sua natureza transnacional, que conduz à necessidade de uma "mundialização" das soluções, o que concita ainda outro tipo de questões, as do Direito Comunitário e do Direito Internacional Público, em relação com o Direito do Ambiente.

Em texto de celebração do aniversário da APRH cabe interrogarmo-nos sobre qual a posição do Direito das Águas neste quadro. Neste sentido, não há porque distinguir o Direito das Águas do Direito do Ambiente. As questões que aquele coloca, ou que se colocam em relação com ele, do ponto de vista das suas conexões com outras áreas do Direito, instrumentos e técnicas jurídicas próprias, corpo próprio de princípios e até mesmo questões das ciências do Ambiente que concita, não se distinguem, no essencial, das que se colocam em relação com o Direito de outros componentes ambientais naturais, como sejam o Direito do Ar, o Direito dos Resíduos ou o Direito do Ruído.

Mais, os objectivos de protecção do ambiente, tal como são hoje equacionados, exigem, na sua prossecução, uma visão integrada que determina que as soluções institucionais e legislativas sejam concebidas segundo essa perspectiva, contra a perspectiva compartimentada do período anterior. Essa perspectiva será a única susceptível de ser bem sucedida face aos avanços tecnológicos que permitem hoje fazer as chamadas transferências de poluição entre componentes ambientais naturais, sempre que a legislação que respeita à protecção de um deles o viabilize economicamente.

De facto, é possível proceder à queima de resíduos, com as consequentes emissões para a atmosfera, que poderão ser fortemente poluentes, evitando a sua deposição e a consequente poluição do solo, tal como é possível fazer a lavagem desses gases e conduzir em seguida as águas residuais poluídas para o meio aquático. O próprio tratamento das águas residuais, se as lamas resultantes do processo forem em seguida simplesmente depositadas e não tratadas, mais não representará do que uma forma de transferência de poluição das águas para o solo, e eventualmente de novo para as águas através da sua lavagem pelas águas pluviais. Os agentes económicos, colocados perante a necessidade de realizarem pesados investimentos tendo em vista a redução dos impactes da sua actividade sobre os diferentes componentes ambientais naturais, avaliarão, de entre as alternativas tecnológicas ao seu dispor, qual aquela que apresenta custos menores, e essa poderá assumir a forma de uma transferência de poluição. 
Uma visão do Direito do Ambiente centrado na Natureza não é isenta de consequências jurídicas. No entanto, uma visão antropocêntrica parece-nos mais sustentável e reconciliável com aquela no plano das soluções jurídicas. É ainda o Homem, na pessoa das gerações futuras, que está no centro das nossas preocupações ambientais e, portanto, do Direito que construímos tendo em vista a sua regulação. São as nossas relações, as relações da presente geração, com essas gerações futuras, com a geração dos nossos filhos e dos nossos netos, que carecem de codificação, perante a crescente capacidade de intervenção e de alteração da Natureza que alcançámos.

Estas preocupações surgem legitimadas pela história recente. O Homem tem hoje ao seu alcance meios que lhe permitem alterar o equilíbrio dos ecossistemas mais resilientes que existem na Terra, desde as florestas tropicais às massas de gelo das calotes polares passando pela camada de ozono da troposfera. Espécies que coabitaram com o Homem neste planeta durante milhões de anos foram já extintas devido à acção directa do Homem ou indirectamente devido à acção predadora deste sobre os seus habitats e os ecossistemas de que dependiam. Constatamos que muitos danos causados pelo Homem sobre os ecossistemas são irreversíveis. É a consciência de que essa acção pode por em causa a sua própria subsistência e os ecossistemas de que depende que leva o Homem à procura de soluções de natureza técnica para os problemas que ele próprio criou e à necessidade de regular a protecção do ambiente.

Esta preocupação é particularmente evidente no Direito das Águas. Sempre estas foram afectadas pela actividade do Homem e de outras espécies. E muitas substâncias estão presentes na água em condições naturais. A Natureza recicla os dejectos humanos tal como o faz com os de outras espécies. Eles são parte dos ecossistemas e alimento de outras espécies, insectos e microorganismos. Ao longo do último século deram-se alterações qualitativas e quantitativas que justificam a necessidade de uma codificação detalhada dos limites permitidos às actividades poluidoras. Por um lado, dá-se uma concentração brutal das cargas poluentes que são descarregadas directamente ou são carreadas para os meios aquáticos pelas águas da chuva, devido às enormes urbes em que se organizou a vida dos homens e aos sistemas de saneamento com que estas são equipadas, o que dificulta a reciclagem natural das águas residuais e dos resíduos sólidos, e por outro lado o Homem, pelo seu domínio das técnicas, produz hoje substâncias artificiais que a Natureza tem dificuldade em reciclar.

Aliás, o Homem produz substâncias visando precisamente esse objectivo: que sejam tóxicas e persistentes e que, portanto, sejam resistentes à acção dos diferentes agentes naturais que asseguram o equilíbrio dos ecossistemas, a saber, a chuva, a insolação, a oxigenação pelo arejamento, a acção dos microorganismos. É o caso dos biocidas ou pesticidas que são lançados na natureza tendo em vista exterminar maciçamente determinadas pragas das culturas, sejam insectos, sejam ervas daninhas, em vista ao aumento das colheitas. O Homem, tal como colocou em risco a sobrevivência do maior animal vivo, a baleia, salvo apenas devido às medidas de protecção entretanto adoptadas, erradicou da face da Terra um microorganismo, o bacilo da varíola.

A Natureza, cujas relações com o Homem o Direito do Ambiente disciplinaria, mais não é, então, do que um mediador que, por razões de utilidade, interpomos entre as gerações cujos interesses se pretendem acautelar. É isso que nos diz o conceito de desenvolvimento sustentável: o desenvolvimento que as gerações presentes promovem é sustentável se não põe em causa as possibilidades de desenvolvimento das gerações futuras. Se preservarmos o ambiente, se protegermos a Natureza, fonte da vida, então estaremos a acautelar o futuro.

Esta visão é ainda suportada pelo princípio da precaução. Em caso de dúvida razoável sobre as consequências ambientais dos actos que nos propomos realizar devemo-nos abster de agir. A defesa da Natureza é, então, a melhor maneira de que dispomos, perante múltiplos factores de incerteza, para acautelarmos os interesses das gerações futuras.

O conceito de desenvolvimento sustentável tem, no entanto, duas faces e como tal tem de ser encarado. Por um lado, a noção de protecção do ambiente e dos recursos naturais em risco, que associamos à defesa dos interesses das gerações futuras, por outro o desenvolvimento económico e social, a criação de riqueza e a resolução dos problemas da pobreza que afligem a presente geração e de que essas gerações futuras virão também a beneficiar. É a ponderação destes interesses colidentes que visa o Direito do Ambiente.

À Administração, através de actos autorizativos e outros actos administrativos, na prossecução do interesse público, cabe fazer a ponderação dos diversos interesses legítimos colidentes em presença: os interesses dos particulares, os seus direitos de iniciativa económica constitucionalmente consagrados, e o interesse comum, o direito ao Ambiente, de igual dignidade. O critério para a resolução destes conflitos é o que decorre do princípio da proporcionalidade: os conflitos entre interesses legítimos colidentes resolvem-se reduzindo o seu alcance por forma a permitir a realização suficiente de cada um sem que nenhum fique afectado no seu núcleo essencial, ou seja, sem diminuir a extensão e o alcance essencial de cada um deles (Amado Gomes, 2000).

O Ambiente, como bem jurídico colectivo, transcende a esfera dos interesses individuais, à qual também pertence, e assume uma dimensão social que o faz elegível a uma protecção ou tutela jurídica própria, em si e por si mesmo. É este o sentido da inscrição, em sede do artigo $9^{\circ}$ da CRP, da protecção e da valorização da natureza e do ambiente e da preservação dos recursos naturais, entre as tarefas fundamentais do Estado. O Ambiente, como bem jurídico colectivo, tem de ser protegido e não podem as suas componentes ser usadas ou apropriadas desordenadamente pelos indivíduos.

Por outro lado, a expressão da dimensão subjectiva do Ambiente é dada pela sua inscrição constitucional entre 
os direitos e deveres fundamentais dos cidadãos. O "direito a um ambiente de vida humano, sadio e ecologicamente equilibrado" é reconhecido pela Constituição da República Portuguesa como um dos direitos fundamentais dos cidadãos, autónomo relativamente a outros direitos (artigo $66^{\circ}$ ). Tal como o dever de o defender. Esse reconhecimento faz dele um direito subjectivo de todo e qualquer cidadão individualmente considerado, sem por de lado a natureza de bem social unitário do Ambiente (Figueiredo Dias, 2002). Neste sentido cada cidadão é titular do direito de acção e indemnização por danos causados ao ambiente, ao seu ambiente de vida humano, sadio e equilibrado, como parte do seu dever de o defender.

Se o Direito do Ambiente não regula apenas as relações dos homens entre si, antes disciplina as relações do Homem com a natureza, ou se regula conflitos de interesses intergeracionais, então como se operacionaliza esse Direito? Por um lado, a Administração Pública, enquanto emanação do Estado que representa os interesses colectivos, no exercício das suas competências, assumindo a protecção do ambiente como tarefa, seja nos actos administrativos próprios visando esse objectivo, como é o caso dos actos autorizativos ambientais, seja assumindo transversalmente, em toda a sua actividade, o respeito pelos princípios básicos do Direito do Ambiente. Por outro lado, a sociedade civil organizada a quem a lei reconhece legitimidade para propor acções em tribunal, seja de recurso dos actos administrativos, seja em vista à prevenção ou cessação de actos lesivos do ambiente, sem que para tal tenha de fazer prova de qualquer interesse directo na demanda (direito de acção popular reconhecido pela Lei n. ${ }^{\circ} 83 / 95$, de 31 de Agosto).

Mas a Administração, nos sistemas de regime administrativo de Administração executiva entre os quais o nosso se situa, goza dos privilégios de execução prévia e presunção de legalidade. Segundo Santos Maçãs (1996) "uma das características fundamentais deste sistema, por oposição aos sistemas de Administração judicial, é a existência de uma Administração que desenvolve a sua actuação segundo princípios que exorbitam do direito comum. A Administração Pública aparece, assim, munida de prerrogativas nas suas relações com os particulares, permitindo-se emitir e executar as suas decisões por autoridade própria, impondo-as unilateral e mesmo coactivamente, sem necessidade do consentimento daqueles, nem mesmo do recurso prévio aos tribunais", ,.. definindo "unilateralmente o direito aplicável num caso concreto, criando, modificando e extinguindo situações jurídicas de outras entidades, cujos efeitos se projectam de forma imediata nas suas esferas jurídicas, com plena força obrigatória e independentemente de qualquer decisão judicial”.

Aos particulares cujos interesses sejam assim afectados assiste o direito de recurso aos tribunais para a impugnação judicial desses actos. A questão do controlo jurisdicional é de extrema importância, na medida em que os tribunais administrativos não podem apreciar o mérito de uma decisão administrativa. Os tribunais podem somente exercer o controle de legalidade, pois de outra forma estariam a invadir a esfera própria do poder administrativo, violando o princípio da separação de poderes. Dado que os actos administrativos se presumem legais até que o particular faça prova do contrário, ainda quando impugnados, e porque essa impugnação raramente conduzirá à suspensão dos actos, eles produzem os seus efeitos, muitas vezes irreversíveis.

Estamos, portanto, perante um quadro de relações desiguais: de um lado, a Administração, visando a prossecução do interesse público, com o seu poder discricionário, do outro o cidadão, com os seus interesses legítimos a acautelar, nomeadamente através da impugnação contenciosa desses actos pelo recurso aos tribunais.

Esta situação não podia deixar de preocupar o legislador, tanto mais quanto os fundamentos técnicos daqueles actos administrativos são geralmente, nos actos administrativos ambientais, de uma muito elevada complexidade e o seu domínio exige conhecimentos avançados de um grande número de ramos das ciências da engenharia e da natureza. Aqueles privilégios de que goza a Administração, na ausência de vinculação, põem em causa o equilíbrio desejado entre o interesse público e o interesse do particular. O reforço do controle jurisdicional dos actos administrativos passa, pois, pelo aumento do número de vinculações legais.

É este o sentido de grande parte da produção legislativa mais recente na área do Direito do Ambiente. Ela visa, por um lado, dotar a Administração de um quadro de normas que lhe permitam determinar as soluções e fundamentar tecnicamente e de forma objectiva as suas decisões, nos actos administrativos que lhe compete praticar, nomeadamente no licenciamento ambiental das actividades económicas, reduzindo a margem de discricionaridade que é sua prerrogativa, e por outro lado, permitir a acção jurisdicional dos tribunais sobre esses actos, reequilibrando as relações dos particulares com a Administração.

Os últimos 25 anos foram férteis em produção legislativa neste domínio, a ponto de se poder falar, com propriedade, no nascimento de um novo ramo do Direito, o Direito do Ambiente. Como em qualquer novo ramo do Direito, as suas normas não estão ainda decantadas e consolidadas. Este processo é tanto mais difícil e complexo quanto todos os dias, literalmente, novas situações, novos produtos, novas técnicas, novos perigos, novos desenvolvimentos surgem que requerem uma nova ponderação dos interesses em presença e, portanto, novas disposições legais, novos normativos e até, a revisão de conceitos e estratégias, tudo tendo em vista o desenvolvimento sustentável.

\section{A LEI DE BASES DO AMBIENTE E OS PRINCÍPIOS E CONCEITOS FUNDAMENTAIS DO DIREITO DO AMBIENTE}

À semelhança do que sucede com outros ramos do Direito, também o Direito do Ambiente se funda sobre um conjunto de princípios fundamentais cuja dilucidação e consolidação acompanham a par e passo a organização e o desenvolvimento deste. A utilidade dos princípios, no Direito, reside fundamentalmente no facto de serem um padrão 
que permite aferir a validade das leis (sendo ilegais as disposições ou regulamentos e os actos administrativos que os contrariem), de serem auxiliares da interpretação de outras normas jurídicas e, finalmente, pela sua capacidade de integração de lacunas. Eles definem um paradigma sobre o qual se estruturam as leis e as suas soluções normativas.

Neste sentido é impressionante a evolução sofrida, nesta matéria, pelo Direito do Ambiente durante o período em análise. Chegados aqui cabe referir a Lei de Bases do Ambiente (LBA), Lei n. ${ }^{\circ} 11 / 87$, de 7 de Abril, que fixa um corpo de princípios e com eles estabelece um novo paradigma ambiental.

Depois de consagrar como princípio geral que "todos os cidadãos têm direito a um ambiente humano e ecologicamente equilibrado e o dever de o proteger, incumbindo ao Estado, por meio de organismos próprios e por apelo a iniciativas populares e comunitárias, promover a melhoria da qualidade de vida, quer individual quer colectiva", retomando fórmulas da CRP, a LBA prossegue com a definição de princípios específicos: princípio da prevenção, do equilíbrio, da participação, da unidade de gestão e acção, da cooperação internacional, da procura do nível mais adequado de acção (princípio da subsidiariedade), da recuperação (do dano ambiental) e da responsabilização. Embora as fórmulas adoptadas nem sempre sejam aquelas que têm vindo a ser consagradas no Direito do Ambiente mais recente, nomeadamente em textos de Direito Comunitário e de Direito Internacional Público, a sua inscrição em diploma de bases de direito constituiu um marco importante na evolução do Direito nacional e não pode deixar de ser assinalada.

Refira-se que são ali omitidos alguns importantes princípios que já à época integravam o nosso Direito interno, por via da sua consagração no Tratado da EU, como é o caso dos princípios do poluidor-pagador e da correcção na fonte, consagrados pelo Acto Único Europeu de 1986, e outros que vinham sendo já referidos em documentos internacionais e actos do Direito Comunitário derivado, como sejam os princípios da precaução e da integração, este último que viria a ser consagrado na CRP (alínea $f$ do n. 2 do artigo $66^{\circ}$ ) aquando da revisão de 1997. Outros princípios importantes estão dispersos pelo diploma, como é o caso do princípio da responsabilidade do produtor pelos resíduos que produza (n. 3 do artigo $24^{\circ}$ ).

$\mathrm{Na}$ LBA propõe-se a adopção de medidas que visem "a adequada delimitação dos níveis de qualidade dos componentes ambientais" (artigo $4^{\circ}$, alínea g). Nos termos da lei são componentes ambientais naturais o ar, a luz, a água, o solo vivo e o subsolo, a flora e a fauna, e componentes ambientais humanos a paisagem, o património natural e construído e a poluição. Cada um destes componentes é objecto de um conjunto de disposições normativas respeitantes à sua protecção, à prevenção da poluição e à promoção da parcimónia do uso. Este é, aliás, um dos traços marcantes deste novo Direito, que diplomas sucessivos vêm aprofundando e densificando, e é particularmente sublinhado em relação com o componente água. O conceito de gestão da água pela procura enforma o diploma sem que, no entanto, lhe seja feita referência explícita.
Surgem na LBA disposições absolutamente inovadoras no Direito Nacional, na substância ou na fórmula adoptada, como sejam: o conceito de conforto em nível de luminosidade como direito pessoal (artigo $9^{\circ}$ ), o combate ao desperdício de água e a promoção da reutilização das águas usadas (a regulamentar através de legislação específica, artigo $10^{\circ}$ ), a defesa e a valorização do solo como recurso natural a utilizar racionalmente e a proteger (artigo $13^{\circ}$ ), a defesa e a valorização das formações vegetais expontâneas (artigo $15^{\circ}$ ), a protecção da fauna, a recuperação dos seus habitats e o combate à introdução de espécies exóticas, e a valorização dos recursos animais, cinegéticos e piscícolas (artigo $16^{\circ}$ ), a valorização da paisagem e a sua defesa como unidade estética e visual e a introdução do conceito da sua gestão (artigo $18^{\circ}$ ), a protecção contra o ruído e a homologação de equipamentos no que se refere às características dos sinais acústicos que produzem (artigo $22^{\circ}$ ), a ênfase na utilização de tecnologias limpas e a defesa da reciclagem e da reutilização para o combate à poluição (artigos $23^{\circ}$ e $24^{\circ}$ ), para referir apenas alguns julgados mais relevantes.

Inovadora é também a sistematização dos instrumentos da política de Ambiente e do ordenamento do território. Nos termos do artigo $27^{\circ}$ da LBA são instrumentos da política do Ambiente e do ordenamento do território: a estratégia nacional de conservação da Natureza, integrada na estratégia europeia e mundial; o plano nacional; o ordenamento integrado do território a nível regional e municipal, incluindo a classificação e criação de áreas, sítios ou paisagens protegidas sujeitos a estatutos especiais de conservação; a reserva agrícola nacional (RAN) e a reserva ecológica nacional (REN); os planos regionais de ordenamento do território, os planos directores municipais e outros instrumentos de intervenção urbanística; o estabelecimento de critérios, objectivos e normas de qualidade para os efluentes e resíduos e para os meios receptores; a avaliação prévia do impacte provocado por obras, pela construção de infra-estruturas, introdução de novas actividades tecnológicas e de produtos susceptíveis de afectarem o ambiente e a paisagem; o licenciamento prévio de todas as actividades potencial ou efectivamente poluidoras ou capazes de afectarem a paisagem; a redução ou suspensão de laboração de todas as actividades ou transferência de estabelecimentos que de qualquer modo sejam factores de poluição; os incentivos à produção e instalação de equipamentos e a criação ou transferência de tecnologias que proporcionem a melhoria da qualidade do ambiente; a regulamentação selectiva e quantificada do uso do solo e dos restantes recursos naturais; o inventário dos recursos e de outras informações sobre o ambiente a nível nacional e regional; o sistema nacional de vigilância e controle da qualidade do ambiente; o sistema nacional de prevenção de incêndios florestais; a normalização e homologação de métodos e aparelhos de medida; as sanções pelo incumprimento do disposto na legislação sobre o ambiente e ordenamento do território; a cartografia do ambiente e do território e; a fixação de taxas a aplicar pela utilização de recursos naturais e componentes ambientais, bem como pela rejeição de efluentes. Previa-se ali ainda que lei especi- 
al viesse a definir as áreas e zonas de grande poluição onde se faria o controlo e se tomariam medidas permanentes em vista às normalização da qualidade do ambiente.

Esta relação de instrumentos da política de Ambiente tem o seu desenvolvimento na própria LBA e o respectivo normativo viria a ser densificado em diplomas publicados nos anos seguintes, que ainda hoje conformam o nosso Direito do Ambiente, como é o caso do licenciamento das actividades poluentes, do ordenamento do território e da avaliação de impactes ambientais.

Em contrapartida, muitas das normas da LBA viriam a revelar-se inadequadas, ou simplesmente irrealistas, e nunca foram implementadas, como aconteceu com a definição das áreas e zonas de grande poluição e a suspensão de laboração das actividades poluentes, ou seriam mais tarde alteradas por outros diplomas entretanto aprovados, ou revogadas, como é o caso da gestão de recursos hídricos por bacias hidrográficas.

A LBA previa a regulamentação de muitas das suas normas no prazo de 1 ano (artigo $51^{\circ}$ ), como condição para a sua entrada em vigor (artigo $52^{\circ}$, n. $^{\circ} 2$ ). Em alguns casos o prazo que mediou entre o enunciado da medida pela LBA e a sua regulamentação foi de tal forma dilatado que a sua eficácia ficou claramente diminuída em relação ao projecto original. Isso aconteceu com a estratégia nacional de conservação da natureza e com o plano nacional, por exemplo. Noutros casos essa regulamentação revela-se insuficiente, parcelar ou imperfeita, como acontece com a regulamentação, prevista no n. ${ }^{\circ} 4$ do artigo $13^{\circ}$, para o uso, a produção e a aplicação de biocidas, pesticidas, herbicidas, adubos, correctivos ou quaisquer outras substâncias similares, e com a regulamentação sobre compostos químicos prevista no artigo $23^{\circ}$.

A LBA veio expandir a esfera de direitos e deveres dos cidadãos em matéria de defesa do ambiente (artigo $40^{\circ}$ e seguintes), aprofundada e regulamentada por actos legislativos subsequentes. Aprovada e publicada na mesma ocasião da LBA, a Lei das Associações de Defesa do Ambiente, Lei n. ${ }^{\circ} 10 / 87$, de 4 de Abril, reconhecia capacidade jurídica e legitimidade a estas associações para usarem vários meios jurisdicionais na prossecução dos seu objectivos. $\mathrm{O}$ direito à protecção jurisdicional efectiva é assegurado pelo direito de acção popular no domínio da protecção do ambiente e da qualidade de vida, inscrito no artigo $52^{\circ}$, n. 3 alínea $a$ da CRP pela revisão constitucional de 1989.

Especificamente para a área do Ambiente, a Lei $n .{ }^{\circ}$ 35/98, de 18 de Julho, que substituiu e revogou integralmente a Lei n. ${ }^{\circ} 10 / 87$, atribui às ONGA (artigo 10) legitimidade para proporem acções judiciais necessárias à prevenção, correcção, suspensão e cessação de actos e omissões de entidades públicas ou privadas que constituam ou possam constituir factor de degradação do ambiente, para intentarem acções judiciais para efectivação da responsabilidade civil e para recorrerem contenciosamente dos actos e regulamentos administrativos que violem as disposições legais que protegem o ambiente.

A LBA cria ainda o Instituto Nacional do Ambiente, dotado de personalidade jurídica e autonomia administrati- va e financeira, destinado à promoção de acções no domínio da qualidade do ambiente, com especial ênfase na formação e informação dos cidadãos e apoio às associações de defesa do ambiente. Este instituto é o primeiro da Administração do Ambiente com estas funções específicas.

A LBA enferma de algumas omissões de monta, apenas explicáveis à luz daquilo que era o entendimento prevalecente na altura sobre o carácter vinculante, ou a sua ausência, do Direito Comunitário. Aqui, como noutras ocasiões, o legislador terá ignorado duas características do Direito Comunitário consagradas no n. ${ }^{\circ} 3$ do artigo $8^{\circ}$ da CRP: a sua aplicabilidade directa e a sua primazia sobre o Direito Nacional. Assim, contra o que seria desejável, a LBA não reflecte a estratégia comunitária de combate à poluição das águas por substâncias perigosas, das directivas 76/464/CEE e 80/68/CEE, que visa a eliminação de umas e a redução da presença de outras nas águas, não lhes fazendo qualquer referência enquanto tais. Do mesmo modo, não confere à valorização dos resíduos a importância estratégica que lhe era já então reconhecida pelo Direito Comunitário.

Esta lei consagra algumas disposições de duvidoso mérito ou fundamento, como sejam a reciclagem da energia (artigo $23^{\circ},{ }^{\circ}{ }^{\circ} 2$ alínea $f$ ), que se ignora o que seja, e a protecção dos montados de sobro e azinho e das sebes vivas, uveiras e muros (artigo $9^{\circ}$ ), a pretexto do direito a um nível de luminosidade conveniente (!). Aliás, há que referir que, se se reconhece um mérito indiscutível à LBA, também não pode ser ignorado que, em muitos aspectos, esta lei não escapa à tentação de tudo regular, sem consideração pelo princípio da proporção e invadindo a esfera de outros direitos fundamentais dos cidadãos. É assim com a universalidade do licenciamento das utilizações das águas, criada pelo artigo $11^{\circ}, \mathrm{n} .{ }^{\circ} 1$, dificilmente compaginável com as disposições do artigo $1385^{\circ}$ e seguintes do Código Civil sobre águas particulares, e cuja utilidade não tem proporção com as dificuldades e as exigências que coloca á Administração; é assim com a proibição "dos processos (de cultivo, presume-se) que impeçam o desenvolvimento normal ou a recuperação da flora e da vegetação espontâneas que apresentem interesses científicos, económicos ou paisagísticos..." (artigo 15\% , n. ${ }^{\circ} 2$ ); é ainda assim com algumas obrigações de "fazer" que são criadas aos particulares, como é o caso da obrigação de execução de trabalhos técnicos, agrícolas e silvícolas, tendo em vista a defesa e a valorização dos solos (artigo 13\% ${ }^{\circ}$ n. ${ }^{\circ}$ ).

A LBA continua a ser uma referência obrigatória do Direito do Ambiente entre nós, pesem embora os anos passados desde a sua entrada em vigor e a evidente perda de actualidade de muitas das suas normas, por força do impulso legislador comunitário e nacional. Esta lei teve desenvolvimentos importantes, no plano legal e institucional, e marcou toda uma geração de diplomas que viriam a ser publicados nos anos seguintes, muitos deles destinados à transposição das directivas comunitárias que Portugal foi encontrar em vigor aquando da sua adesão à CEE em 1986. 


\section{A CRIAÇÃO DO MINISTÉRIO DO AMBIENTE E AS DIRECTIVAS DA PRIMEIRA GERAÇÃO}

Um passo importante no sentido da valorização da problemática ambiental entre nós foi dado em 1991, com a criação do Ministério do Ambiente e dos Recursos Naturais (MARN), cujas atribuições e competências não têm deixado de crescer desde então. A tutela do Ambiente havia estado atribuída anteriormente ao Ministério do Planeamento e Administração do Território, depois da existência fugaz de um Ministério da Qualidade de Vida.

A orgânica do MARN veio a ser estabelecida em 1993, pelo Decreto-Lei n. ${ }^{\circ} 187 / 93$, de 24 de Maio. Foram então criados o Instituto da Água (INAG), organismo sectorial sucessor dos velhos Serviços Hidráulicos e que passou a integrar as competências relativas à qualidade da água, a Direcção Geral do Ambiente (DGA), serviço central de coordenação do Ministério que sucedeu à DG Qualidade do Ambiente e que passou a deter as competências sectoriais relativas aos resíduos, à vigilância radiológica e às avaliações de impactes ambientais, o Instituto da Conservação da Natureza (ICN), que sucedeu ao Serviço Nacional de Parques, Reservas e Conservação da Natureza, o Instituto de Promoção Ambiental (IPAMB), que sucedeu ao Instituto Nacional do Ambiente criado pela LBA, o Instituto de Meteorologia (IM), que sucedeu ao Instituto Nacional de Meteorologia e Geofísica, com as competências relativas à protecção da qualidade do ar, o Instituto do Consumidor (IC), que sucedeu ao Instituto Nacional de Defesa do Consumidor, e as Direcções Regionais do Ambiente e dos Recursos Naturais (DRARN, mais tarde DRA, apenas, e depois DRAOT, quando passaram a integrar as competências em matéria de ordenamento do território), serviços desconcentrados do Ministério, criadas a partir das direcções de serviço de ambiente das Comissões de Coordenação Regional (CCR) e dos departamentos desconcentrados da Administração hidráuli$\mathrm{ca}$, às quais incumbe assegurar, no âmbito das respectivas regiões (as regiões-plano) a execução da política e objectivos nacionais da área do Ambiente, recursos naturais e consumidor, em coordenação com os serviços centrais do Ministério. Foi ainda criada a Comissão Consultiva do Ambiente, o órgão de consulta do Ministro do Ambiente e Recursos Naturais para efeitos de apreciação e concertação das suas políticas e actividades, que não viria a ser constituído e seria mais tarde substituído pelo Conselho Nacional do Ambiente e do Desenvolvimento Sustentável (Decreto-Lei n. ${ }^{\circ}$ 221/97, de 20 de Agosto).

A subordinação do Ordenamento do Território à mesma tutela do Ambiente veio a ter lugar já em 1999, com a criação do Ministério do Ambiente e do Ordenamento do Território cuja orgânica foi aprovada pelo Decreto-Lei n. ${ }^{\circ}$ 120/2000, de 4 de Julho.

Os últimos anos da década de 80 e os primeiro da década de 90 foram especialmente produtivos. Foi então ensaiada uma reforma da Administração do sector da água, com a aprovação dos Decreto-Lei n. ${ }^{\circ}$ 70/90, de 2 de Mar- ço, e Decreto-Lei n. ${ }^{\circ} 74 / 90$, de 7 de Março, o primeiro sobre o regime dos bens do domínio público do Estado e o segundo fazendo a transposição das normas de qualidade das águas e águas residuais das directivas comunitárias que estavam em vigor no momento da adesão de Portugal à CEE. Foi também aprovado o primeiro Regulamento Geral do Ruído (Decreto-Lei n. ${ }^{\circ} 251 / 87$, de 24 de Junho) e o quadro jurídico da gestão dos resíduos foi pela primeira vez definido entre nós (Decreto-Lei n. ${ }^{\circ}$ 488/85, de 25 de Novembro). Por seu turno, o Decreto-Lei n. ${ }^{\circ} 352 / 90$, de 9 de Novembro, veio estabelecer o regime de protecção e controlo da qualidade do ar e revogar a legislação anterior. Quanto ao Decreto-Lei n. ${ }^{\circ}$ 186/90, de 6 de Junho, introduziu no Direito interno as normas constantes da directiva 85/337/CEE relativa à avaliação de impactes ambientais.

Todos estes diplomas tiveram um grande impacte sobre a protecção dos diferentes componentes ambientais naturais, dando concretização aos objectivos que presidiram à LBA e criando uma dinâmica que não mais se extinguiria. Muitas das suas normas viriam a ser densificadas, alteradas, substituídas posteriormente, mas o Direito do Ambiente ficou então fundado.

O primeiro destes diplomas, o Decreto-Lei n. ${ }^{\circ}$ 70/90, merece especial atenção nesta oportunidade, embora não tenha chegado a determinar significativamente a gestão da água que se praticou entre nós dado que viria a ser derrogado, no que respeita ao modelo institucional, pela orgânica do MARN, em 1993, e na matéria respeitante ao regime de licenciamento das utilizações do domínio hídrico pelo Decreto-Lei n. ${ }^{\circ}$ 46/94, de 22 de Fevereiro.

$\mathrm{Na}$ linha das soluções encontradas noutros países europeus, particularmente em Espanha e em França cujo sistema institucional de gestão de recursos hídricos terá sido analisado, a água é encarada, no Decreto-Lei n. ${ }^{\circ}$ 70/90, "como factor de produção e como recurso estruturante de desenvolvimento, pelo que o seu planeamento e gestão são orientados numa perspectiva de racionalidade económica, enquadrada pela necessidade de garantia de uma disponibilidade adequada, quer de quantidade, quer de qualidade" (do preâmbulo ao diploma).

Tal como acontecia já naqueles países, o conceito "utilização da água" passava a ser ali encarado no sentido lato do termo, que inclui a utilização como meio receptor, quer de descargas de efluentes, quer de poluição difusa. Para promover o planeamento e a gestão dos recursos hídricos de uma forma racional, optava-se por definir como unidade de gestão a bacia hidrográfica, conjuntos de bacias hidrográficas ou zonas consideradas afins numa óptica de utilização da água, criando para o efeito administrações de recursos hídricos (ARH). Ao Instituto Nacional da Água (INAG) a criar, sucessor dos Serviços Hidráulicos criados em 1892, caberiam poderes de superintendência financeira e técnica das ARH, que seriam seus organismos desconcentrados. A solução que viria a ser implementada em 1993 foi outra, a das DRARN com autonomia relativamente ao INAG e de âmbito territorial coincidente com o das CCR.

Papel de relevo era atribuído às associações de utilizadores, concebidas para "libertar a Administração Pública 
de responsabilidades e encargos por certo melhor exercidos pelos seus directos beneficiários", nos dizeres do preâmbulo do diploma, lamentavelmente omisso no que concerne à atribuição de recursos financeiros a estes parceiros.

O Decreto-Lei n. ${ }^{\circ}$ 70/90 define o regime de bens do domínio público hídrico do Estado, incluindo a respectiva administração e utilização. Deste regime era excluído o domínio público marítimo, que se regeria por legislação própria, sem prejuízo da aplicação das taxas e sanções ali previstas. No plano dos princípios, o diploma desenvolve os enunciados na LBA, como sejam: o respeito pela bacia hidrográfica, como unidade de planeamento e gestão; o enquadramento das acções de intervenção no domínio público hídrico num processo de planeamento global e integrado, assente na especificidade de cada bacia; a articulação do planeamento e administração dos recursos hídricos com os planeamentos sectoriais, as estratégias de desenvolvimento regional, o ordenamento do território e a conservação e protecção do ambiente e; a definição da água como um bem de consumo ou factor de produção estruturante do desenvolvimento, ao qual é atribuído um valor e um custo.

A administração e gestão dos recursos hídricos desenvolver-se-ia nos níveis central, (funções de coordenação nacional, de representação internacional e de promoção de grandes objectivos ou de iniciativas de dimensão nacional, através do INAG), de bacia ou região hidrográfica (funções de autoridade do domínio público hídrico, nomeadamente de licenciamento e fiscalização, e de promoção e apoio ao fomento hidráulico, assente num processo de planeamento integrado, através das ARH) e sub-regional ou local (onde prevaleceriam os utilizadores dos recursos hídricos do domínio público hídrico, promovendo e realizando acções de fomento hidráulico, incluindo a realização e exploração de infra-estruturas hidráulicas). Os conselhos regionais da água a criar seriam órgãos consultivos do Governo no âmbito da gestão dos recursos hídricos a nível regional e funcionariam junto de cada $\mathrm{ARH}$.

A ideia destes Conselhos viria a ser retomada pelo Decreto-Lei n. ${ }^{\circ} 45 / 94$, agora enquanto órgãos consultivos de planeamento hidráulico regional (artigo $11^{\circ}, \mathrm{n} .{ }^{\circ} 1$ ), e ampliada com a criação do Conselho Nacional da Água, órgão consultivo do Governo (artigos $9^{\circ}$ e $10^{\circ}$ que seriam revogados pelo Decreto-Lei n. ${ }^{\circ} 166 / 97$, de 2 de Julho, que aprovou a nova estrutura, competências e funcionamento deste órgão).

O Decreto-Lei n. ${ }^{\circ}$ 70/90 considerava utilização do domínio hídrico qualquer acto ou actividade que provocasse alterações quantitativas ou qualitativas do estado das águas, leitos ou margens, nomeadamente captações ou desvios, retenção ou rebaixamento de nível, rejeição de efluentes ou adição de substâncias, pontualmente ou de forma difusa, extracção de inertes e, bem assim, qualquer ocupação de espaço no domínio hídrico, qualquer que fosse o seu fim. Esses fins poderiam ser: a captação de água ou extracção de inertes, a ocupação por quaisquer infra-estruturas, designadamente as destinadas à produção de energia, à realização de culturas biogenéticas, ao transporte e à prática de actividades desportivas ou de lazer e as descargas de substâncias líquidas ou sólidas.
Estas utilizações do domínio público hídrico do Estado careciam de licenciamento e os pressupostos gerais necessários enumerados eram a abstenção da prática de actos ou actividades que causassem exaustão ou degradação qualitativa dos recursos hídricos e outros impactes sobre o ambiente, a abstenção da prática de actos ou actividades que inviabilizassem usos alternativos considerados prioritários e a conformação com as orientações do planeamento da bacia ou região hidrográfica.

Estas normas não eram propriamente revolucionárias, nem representavam um corte profundo com o Direito anterior. Os Serviços Hidráulicos já possuíam uma estrutura desconcentrada, por regiões hidrográficas, as chamadas "Hidráulicas", com as funções de autoridade de Estado agora atribuídas às ARH. O licenciamento era já feito, ainda que de forma incipiente, pelas Hidráulicas, com a observância de critérios semelhantes aos que agora se introduziam. Não havia normas de qualidade em que se apoiasse esse licenciamento e, obviamente as circunstâncias, neste particular, alteraram-se, mas mais por força da aprovação, na mesma ocasião, do Decreto-Lei n. ${ }^{\circ}$ 74/90.

Inovadoras eram as disposições relativas ao planeamento de recursos hídricos, que viriam a ser regulamentadas pelo Decreto-Lei n. ${ }^{\circ}$ 45/94 (que retoma muita delas, altera outras e aprofunda e desenvolve outras ainda, derrogando implicitamente o Decreto-Lei n. ${ }^{\circ} 70 / 90$ nestas matérias). Assim, no que concerne aos requisitos a que deve obedecer o planeamento de recursos hídricos, são adoptados os seguintes: globalidade, baseando-se numa abordagem conjunta e interligada dos aspectos técnicos, económicos, ambientais e institucionais; racionalidade, visando a optimização da exploração das várias origens da água e a satisfação das várias necessidades, articulando a procura e a oferta e salvaguardando a preservação quantitativa e qualitativa dos recursos hídricos, bem como uma aplicação económica dos recursos financeiros; integração, em articulação com o planeamento dos sectores utilizadores, com o planeamento regional, com o ordenamento do território e com a conservação e protecção do ambiente; coordenação, visando a satisfação articulada de objectivos de curto, médio e longo prazo, e; participação, envolvendo agentes económicos e o público em geral e visando o alargamento de consensos.

As orientações dos planos de recursos hídricos são, nos termos do artigo $8^{\circ}$ do Decreto-Lei n. ${ }^{\circ} 70 / 90$, pressupostos gerais necessários de qualquer forma de licenciamento, como seria desejável e tal como viria a ser consagrado pelo Decreto-Lei n. ${ }^{\circ} 46 / 94$ relativo ao regime de utilização do domínio hídrico (artigo $4^{\circ}$, n. $^{\circ} 1$ ).

Mas o Decreto-Lei n. ${ }^{\circ}$ 70/90 assume também a valorização dos recursos hídricos enquanto recurso estruturante do desenvolvimento. Neste sentido, prevê-se nele que as acções de fomento hidráulico possam ser da iniciativa dos utilizadores interessados, individualmente ou associados, ou do Estado na ausência de iniciativa destes, nomeadamente nas obras de fins múltiplos e colectivos com impacte nacional e regional de elevado interesse sócioeconómico. Ao mesmo tempo faz-se depender as acções de iniciativa do Estado ou dos utilizadores do acordo ex- 
presso destes quanto à realização do empreendimento e de todas as acções complementares necessárias à sua execução e financiamento, bem como da assunção das obrigações decorrentes da utilização do domínio público hídrico, da obrigação de amortizar o custo da obra e da garantia de assunção dos encargos de exploração e conservação. A promoção de acções de fomento hidráulico por parte dos utilizadores pode contar com apoio técnico-financeiro da ARH com jurisdição na área respectiva, através da figura do contrato-programa sempre que seja feita demonstração da inviabilidade da actividade proposta sem o apoio público, técnico ou financeiro. O financiamento pelo Estado assume a forma de participação directa no investimento inicial, reembolsável ou a fundo perdido, ou de apoio na contratação de empréstimos. A exploração e conservação de empreendimentos hidráulicos fica à exclusiva responsabilidade dos utilizadores respectivos, que a podem contratar com entidades prestadoras de serviços nesta área. No caso de acções da iniciativa do Estado, deverão os empreendimentos, logo que aptos para utilização, ser entregues aos respectivos utilizadores, mediante licença de utilização. Os utilizadores de empreendimentos colectivos, de fins únicos ou múltiplos, podem constituir-se em associação com vista à exploração e conservação dos mesmos.

As utilizações do domínio público hídrico, incluindo a rejeição de efluentes e qualquer que seja a natureza e personalidade jurídica do utilizador, são sujeitas pelo Decreto-Lei n. ${ }^{\circ}$ 70/90 ao pagamento de uma taxa denominada "taxa de utilização". A liquidação e cobrança daquela taxa competiria às ARH, ficando a constituir receita própria sua, destinada ao financiamento de investimentos de protecção e melhoria dos recursos hídricos e à cobertura das suas despesas de exploração, sendo a respectiva repartição fixada no âmbito do processo de aprovação do plano e orçamento anuais. Por outro lado, os beneficiários de infra-estruturas hidráulicas ou de saneamento básico estão sujeitos ao pagamento de uma taxa de exploração, conservação e beneficiação. A liquidação e cobrança desta taxa compete às entidades gestoras das infra-estruturas, ficando a constituir receita própria destas e das entidades financiadoras dos investimentos, na proporção a estabelecer em diploma próprio.

Como vemos, estas disposições relativas ao regime económico-financeiro das utilizações do domínio público hídrico continuam actuais e, com alguns ajustamentos, são compagináveis com as obrigações criadas pela DQA em matéria de recuperação de custos dos serviços hídricos. Infelizmente a sua aplicação ficou muito aquém das expectativas, como viria a acontecer com o Decreto-Lei n. ${ }^{\circ}$ 47/94, de 22 de Fevereiro, que era suposto regulamentar esta matéria mas que, à falta da publicação das portarias que fixam os coeficientes necessários ao cálculo das taxas nele previstas, tem hoje uma aplicação muito limitada.

Aprovado na mesma ocasião, mais inovador e complementar do Decreto-Lei n. ${ }^{\circ} 70 / 90$, o Decreto-Lei n. ${ }^{\circ}$ 74/90 fazia a transposição de um conjunto vasto de directivas de qualidade das águas e águas residuais para o nosso Direito interno. Estas normas complementavam as dispo- sições daquele diploma no que respeita aos requisitos a que deve obedecer o licenciamento das utilizações do domínio público hídrico. A sua importância foi enorme, pese embora não ter sido alcançado o objectivo de transposição conforme que se havia proposto. Essas dificuldades viriam a ser resolvidas com o Decreto-lei n. ${ }^{\circ}$ 236/98, de 1 de Agosto, que o veio a revogar, e com outros actos legislativos posteriores que vieram fazer a transposição das directivas sobre substâncias perigosas.

As directivas comunitárias transpostas pelo DecretoLei n. ${ }^{\circ}$ 74/90 eram as directivas para o sector da água ditas da primeira geração: a directiva sobre a qualidade das águas superficiais destinadas à produção de água potável, as directivas sobre águas piscícolas, águas conquícolas e águas balneares, assim como as directivas relativas às águas destinadas ao consumo humano e à poluição causada por determinadas substâncias perigosas lançadas no meio aquático. Excluídas estas últimas, todas as demais directivas obedecem ao mesmo esquema normativo: fixam objectivos de qualidade para as águas, na acepção de meios hídricos que viria a ser adoptada na DQA, em função do seu uso, prevêem a elaboração de programas de medidas destinados à melhoria da sua qualidade, a monitorização dessas águas, tendo em vista a verificação de conformidade, e a elaboração de relatórios periódicos. Todas essas normas admitem derrogações temporárias (casos de força maior, como sejam no seguimento de intempéries que prejudiquem temporariamente a qualidade das águas) ou permanentes (enriquecimento natural das águas com certas substâncias).

Conforme já referimos, o mesmo ano de 1990 assistiu à adopção de legislação profundamente inovadora em matéria da protecção e melhoria da qualidade do ar, com a aprovação do Decreto-Lei n. ${ }^{\circ}$ 352/90, de 9 de Novembro. Este diploma visou a criação de um quadro normativo adequado para a gestão do ar, de forma a proteger a saúde pública, o bem-estar das populações e a conservação da natureza, estabelecendo medidas obrigatórias, preventivas e correctivas, para assegurar que os níveis dos poluentes atmosféricos não ultrapassem os valores máximos das normas de qualidade do ar. Ficou assim criado o quadro normativo que viria a possibilitar mais tarde a transposição da directiva relativa às grandes instalações de combustão e à prevenção da poluição atmosférica provocada por incineradoras, e das directivas relativas aos valores limite para o dióxido de enxofre, as partículas em suspensão, o dióxido de azoto, o monóxido de carbono e o ozono (Portaria n. ${ }^{\circ}$ 286/93, de 12 de Março).

Entre os instrumentos fundamentais do sistema de protecção e controlo da qualidade do ar estabelecido pelo Decreto-Lei n. ${ }^{\circ}$ 352/90 estão os programas regionais de controlo da poluição atmosférica, o fomento da utilização de tecnologias limpas e de combustíveis pouco poluentes, o desenvolvimento de uma política integrada de preservação dos componentes ambientais, visando evitar as transferências de descargas de poluentes de um meio receptor para outro, a aplicação do princípio do poluidor-pagador, designadamente através da fixação de uma taxa sobre a rejeição de efluentes para a atmosfera e o licenciamento 
prévio dos estabelecimentos poluentes, e a utilização de instrumentos de planeamento adequados à prevenção e redução da poluição atmosférica.

Os valores limite de emissão, visando a protecção do ambiente e da saúde humana, aplicar-se-iam a todas as emissões de poluentes atmosféricos emitidos por fontes fixas de qualquer estabelecimento industrial e constariam de portaria a publicar. Esses valores limite de emissão (VLE), uns de aplicação geral, outros de aplicação sectorial, viriam a ser fixados pela Portaria n. ${ }^{\circ}$ 286/93 que estabelece também os valores limite e valores guia de concentração de poluentes no meio e condições de licenciamento e monitorização.

A aplicação deste diploma, à semelhança do que aconteceu com idênticos diplomas para o sector das águas, veio a revelar-se muito insuficiente e os problemas persistiram. O Decreto-Lei n. ${ }^{\circ} 276 / 99$, de 23 de Julho, veio definir as linhas de orientação da política de gestão da qualidade do ar e transpor para a ordem jurídica interna a directiva 96/62/CE, do Conselho, de 27 de Setembro, relativa à avaliação e gestão da qualidade do ar ambiente, a qual institui uma nova filosofia e orientação relativa à avaliação e gestão da qualidade do ar ambiente através da definição e estabelecimento de objectivos de qualidade, da sua avaliação com base em métodos e critérios comuns, e sua disponibilização ao público, nomeadamente através de limiares de alerta. É já não apenas a preservação mas também a melhoria dessa qualidade que é visada.

Especial atenção é dedicada ao ozono, para o qual, sempre que se verifique o risco dos valores limite ou limiares de alerta serem excedidos, as DRA estabelecem planos de acção imediata a fim de reduzir este risco e limitar a duração da sua ocorrência, podendo prever, conforme os casos, medidas de controlo e, se necessário, de suspensão das actividades, incluindo o tráfego automóvel, que contribuam para que os valores limite sejam excedidos.

Ainda em 1990 foram transpostas para o Direito interno, pelo Decreto-Lei n. ${ }^{\circ}$ 186/90, de 6 de Junho, as normas constantes da directiva comunitária relativa à avaliação dos efeitos de determinados projectos públicos e privados no ambiente, que dava concretização aos objectivos que presidiram à Lei de Bases do Ambiente.

Nos termos deste diploma, a aprovação de projectos que, pela sua natureza, dimensão ou localização, se considerassem susceptíveis de provocar incidências significativas no ambiente, ficava sujeita a um processo prévio de avaliação do impacte ambiental (AIA), como formalidade essencial. A AIA atende aos efeitos directos e indirectos dos projectos sobre os factores Homem, fauna, flora, solo, água, ar, clima, paisagem, bens materiais e património cultural, e atende ainda à interacção destes factores. Profundamente inovador entre nós à época, no âmbito do processo da AIA é assegurada uma consulta do público interessado, com uma divulgação prévia dos estudos efectuados e respectivos resultados, bem como uma explicitação dos elementos caracterizadores do empreendimento em análise, de molde a permitir uma alargada participação das entidades interessadas e dos cidadãos na apreciação do projecto. As decisões finais tomadas sobre os projectos apreciados nos termos deste diploma, bem como os respectivos processos, são objecto de divulgação pública.

Este diploma veio a ser revogado e substituído pelo Decreto-Lei n. ${ }^{\circ}$ 69/2000, de 3 de Maio, que aprofunda a consulta ao público, cria o instituto da pós-avaliação, destinado a assegurar o melhor acompanhamento, pela Administração do Ambiente, do projecto aprovado, estabelece a faculdade de o proponente poder apresentar uma proposta de definição do âmbito dos estudos de impacte ambiental, tendo em vista assegurar que esses estudos cubram, à partida, os aspectos considerados necessários a uma correcta avaliação desses impactes, e estabelece o carácter vinculativo da declaração de impacte ambiental, assegurando um primado dos valores conservacionistas ambientais sobre todos os demais valores.

Esta medida não foi acompanhada por uma qualificação do processo de decisão e das comissões que dela se ocupam, por forma a garantir uma adequada ponderação de todos os valores em presença e a concertação de interesses. Em consequência, assiste-se a um elevado déficit de ponderação de outros valores, que não os estritamente conservacionistas, com consequências severas sobre o exercício de outros direitos juridico-constitucionalmente tutelados.

A gestão de resíduos em sentido lato, englobando os resíduos urbanos, industriais e hospitalares, merece enquadramento legal, pela primeira vez em Portugal, em 1985. O Decreto-Lei n. ${ }^{\circ} 488 / 85$, de 25 de Novembro, deu suporte legal às preocupações existentes em matéria de gestão de resíduos, que tinham a ver, por um lado, com a prevenção da produção e, por outro lado, com a necessidade de se criar um sistema de registo obrigatório de resíduos que permitisse um conhecimento concreto e fiável das quantidades de resíduos gerados, sua caracterização e destino final, bem como a definição de responsabilidades.

Dez anos mais tarde, e perante o evidente progresso técnico e cientifico, tornou-se necessário proceder à reestruturação e adequação do quadro normativo vigente. Surgiu então o Decreto-Lei n. ${ }^{\circ} 310 / 95$, de 20 de Novembro. Este documento legal transpôs para a ordem jurídica interna as directivas comunitárias relativas a resíduos e revogou o Decreto-Lei n. ${ }^{\circ} 488 / 85$.

Este Decreto-Lei n. ${ }^{\circ}$ 310/95 estabeleceu as regras a que ficaram sujeitas as operações de gestão de resíduos, a saber: recolha, armazenagem, transporte, valorização e eliminação. Reafirmou os objectivos da gestão de resíduos (redução, valorização e eliminação) bem como a obrigatoriedade de registo identificativo por parte de quem efectuar qualquer operação de gestão. Introduziu uma alteração em sede da responsabilidade pela gestão de resíduos, que deixou de ser exclusiva do detentor e passou a ser, em primeira linha, do produtor. Estabeleceu regras quanto ao licenciamento das operações de gestão de resíduos e definiu a elaboração de um Programa Nacional de Gestão de Resíduos. Na sequência deste diploma foi publicada a Portaria n. ${ }^{\circ}$ 15/96, de 23 de Janeiro, que identifica as operações de eliminação e valorização ali previstas.

Em face das novas opções políticas adoptadas e da experiência adquirida, entendeu-se que seria necessária 
alterar o Decreto-Lei n. ${ }^{\circ} 310 / 95$, de 20 de Novembro. O novo diploma legal, Decreto-Lei n. ${ }^{\circ} 239 / 97$, de 9 de Setembro, confirma o princípio da responsabilidade do produtor, introduz um mecanismo autónomo de autorização das operações de gestão e consagra uma nova categoria de resíduos, "outros tipos de resíduos", que permite abranger determinados resíduos não caracterizáveis como urbanos, industriais ou hospitalares. Estabelece também a obrigatoriedade do envio às autoridades competentes, pelos industriais, do registo de resíduos produzidos.

A sujeição de todas as operações de gestão de resíduos à autorização do Ministério do Ambiente veio permitir um maior controlo destas operações. Particularmente importante neste aspecto foi a Portaria n. ${ }^{\circ}$ 335/97, de 16 de Maio, que fixou as regras a que fica sujeito o transporte interno de resíduos e que constitui um instrumento de controlo e fiscalização do movimento de resíduos, por permitir controlar a fonte, o destino, as quantidades e o tipo de resíduos que circulam no país. Os diplomas legais mencionados são estruturais do ponto de vista da gestão de resíduos em geral, exprimindo os princípios hierárquicos da política comunitária neste domínio: prevenção (redução), valorização (reciclagem e valorização energética) e eliminação. Estes princípios hierárquicos estão também expressos na Estratégia Nacional de Gestão de Resíduos Industriais.

A dimensão e gravidade que assume no nosso país o problema dos resíduos industriais, em particular no que respeita às consequências ambientais da ausência de tratamento adequado, motivou o Conselho de Ministros à aprovação de uma Resolução, a RCM n. ${ }^{\circ}$ 98/97, de 25 de Junho, na qual é reafirmado o princípio, já consagrado há longo tempo na legislação nacional e comunitária, da responsabilidade do produtor pelo destino a dar aos resíduos que produza, extrapolando-a ao caso dos produtos que, após utilização pelos consumidores, dão origem a resíduos. É o caso das embalagens que, de acordo com a legislação nacional e comunitária, após utilização devem ser retomadas pelos respectivos embaladores, que são considerados responsáveis pelo seu destino.

Não sendo viável evitar a produção de um resíduo (estratégia da prevenção), a alternativa a adoptar será então a sua valorização. Esta alternativa pode traduzir-se na reintrodução do resíduo no ciclo produtivo, utilizando-o como matéria-prima, ou o seu aproveitamento na produção de energia (valorização energética), reservando o tratamento e a deposição aos casos em que não seja viável a sua valorização.

Uma das componentes da estratégia de gestão de resíduos industriais consiste da sua separação dos restantes tipos principais de resíduos (urbanos, hospitalares e outros). Esta necessidade resulta não só da sua natureza, a requerer tratamento diferenciado, mas também do facto de a respectiva responsabilidade caber a entidades distintas, havendo ainda lugar à separação entre os resíduos industriais perigosos e não perigosos, dado que são diferentes os correspondentes métodos de gestão a considerar, nomeadamente no que concerne à recolha e transporte, tipos de valorização, tratamento e destino final.
A distinção entre resíduos perigosos e não perigosos assenta em critérios objectivos, válidos no espaço da UE, que deram lugar à publicação, quer do Catálogo Europeu de Resíduos, quer da Lista de Resíduos Perigosos, adoptados entre nós na forma de uma portaria conjunta dos Ministros da Economia, da Agricultura, do Desenvolvimento Rural e das Pescas, da Saúde e do Ambiente (Portaria n. ${ }^{\circ}$ 818/97, de 5 de Setembro).

No que respeita aos resíduos industriais perigosos, a RCM n. ${ }^{\circ}$ 98/97 mantém os métodos principais já anteriormente previstos, designadamente a incineração, o tratamento físico-químico e a deposição em aterro, conforme se mostre adequado à sua natureza. Assegurada a possibilidade técnica de serem respeitados, com a co-incineração nos fornos das cimenteiras, os requisitos ambientais exigidos pela legislação nacional e europeia, a RCM preconizava a adopção desta solução quando viável, encaminhando para a exportação os restantes resíduos desta categoria.

Quanto à unidade de tratamento físico-químico de resíduos industriais perigosos, os dados disponíveis indicam a infra-estrutura já instalada em Águeda como adequada e suficiente para tratar os resíduos produzidos no país que necessitam deste tipo de tratamento. Quanto à deposição em aterro destes resíduos, é também introduzida uma alteração importante na orientação até então vigente, cabendo às entidades privadas identificar localizações adequadas, efectuar os respectivos estudos de impacte ambiental e propor os respectivos projectos. Ao Governo cabe assumir, nos termos da lei, a responsabilidade de autorizar essas infra-estruturas e de apoiar, na medida do possível, o seu financiamento, com recurso aos fundos comunitários disponíveis e investimentos públicos necessários para garantir a manutenção dos padrões ambientais da região onde vierem a ser instaladas.

Quanto aos resíduos industriais não perigosos, a estratégia preconizada pela RCM privilegia a respectiva integração no quadro dos mecanismos de gestão dos resíduos sólidos urbanos (RSU), tendo em conta a entrada em funcionamento de numerosos sistemas multimunicipais e municipais, concebidos e dimensionados para o tratamento destes resíduos. Considera a RCM estarem criadas as condições para que os mesmos sistemas possam dar também resposta ao problema dos resíduos industriais, bastando para tal que a natureza destes resíduos e as respectivas quantidades sejam compatíveis com as novas infra-estruturas, em particular com a área disponível dos aterros onde, se necessário, poderão ser abertas novas células, específicas para este tipo de resíduos. Fica garantida, assim, a separação entre a gestão dos resíduos industriais e a gestão dos RSU, embora possam ser utilizados meios e infra-estruturas comuns, sem prejuízo da criação de novas empresas.

Note-se, no entanto, que, como decorre dos princípios gerais acima mencionados, a recolha dos resíduos industriais terá de ser sempre autónoma da recolha dos resíduos urbanos. Os tipos de resíduos a receber por cada infra-estrutura de tratamento terão de ser objecto de um contrato prévio com cada produtor, cabendo aos industriais fazer a separação dos resíduos pelas várias categorias e 
tipos de tratamento. A entrada dos resíduos nas infraestrutura dependerá obrigatoriamente da realização de um procedimento de controlo que confirme que as características dos resíduos respeitam as condições do contrato. Assegurar-se-á, desta maneira, que não serão recebidos resíduos perigosos em infra-estruturas concebidas para resíduos não perigosos.

A estratégia delineada para os resíduos industriais é estendida pela RCM, com as devidas adaptações, a resíduos que possam ter outras origens, entre os quais se contam os óleos usados, os veículos em fim de vida e outras sucatas, os pneus usados, as lamas das estações de tratamento de águas residuais, os resíduos do sector da construção civil, os acumuladores e pilhas usadas, os resíduos de equipamentos eléctricos e electrónicos, os PCB e os CFC.

A especial sensibilidade ambiental da incineração de resíduos perigosos justificou a produção de legislação específica para esta solução de destino final de resíduos industriais perigosos, o que veio a acontecer com a aprovação do Decreto-Lei n. ${ }^{\circ}$ 273/98, de 2 de Setembro, que transpõe para o direito interno as disposições da directiva comunitária pertinente e define as acções preventivas a adoptar para proteger o ambiente contra as emissões provenientes destas instalações. São adoptados VLE de poluentes, disposições especiais relativamente às emissões de dioxinas e furanos e disposições para os casos em que os VLE sejam excedidos, bem como para as paragens, perturbações ou avarias dos sistemas de depuração tecnicamente inevitáveis, tudo isto tendo em consideração que a incineração de resíduos perigosos deve ser conduzida de forma a minimizar a transferência de poluição e os seus reflexos transfronteiriços.

Infelizmente, como é sabido, a solução de coincineração de resíduos industriais perigosos nos fornos das cimenteiras foi abandonada, contra o Parecer da Comissão Científica Independente criada para o controlo e fiscalização ambiental desta operação pelo Decreto-Lei n. ${ }^{\circ}$ 120/99, de 16 de Abril, e o grave problema ambiental que representa a actual situação de depósito destes resíduos continua por resolver e, o que é pior, sem solução à vista.

\section{ACTOS AUTORIZATIVOS AMBIENTAIS}

O licenciamento prévio de todas as actividades potencial ou efectivamente poluidoras ou capazes de afectarem a paisagem é um dos mais importantes instrumentos do Direito do Ambiente e está previsto na LBA, no seu artigo $27^{\circ}$ já referido. Por outro lado, a mesma lei prevê que todas as utilizações da água carecem de autorização prévia de entidade competente, devendo essa autorização ser acompanhada da definição dos respectivos condicionantes (artigo $11^{\circ}$, n. $^{\circ} 1$ ).

Os actos autorizativos ambientais assumem uma função preventiva de actividades lesivas do ambiente. O Direito do Ambiente coloca os interesses ambientais no conjunto de ponderações a ter em consideração pelos órgãos da Administração nos procedimentos decisórios (a este respeito ver Amado Gomes, 2000).
O condicionamento do início de qualquer actividade, ou da sua continuação, à obtenção de um título autorizativo ambiental, é o instrumento mais poderoso ao alcance da Administração Pública em vista à protecção do ambiente. É pelo licenciamento das actividades potencialmente nocivas para o ambiente que pode ser evitada a produção de um dano antes de ele ter ocorrido (em obediência ao princípio da prevenção, que proclama a preferência por medidas preventivas em relação às coactivas). Os actos autorizativos ambientais são ainda os instrumentos mais poderosos para a implementação do princípio do poluidor-pagador (PPP).

À luz do mais recente Direito Comunitário, estes dois princípios assumem contornos mais imperativos e mais precisos. Tendencialmente, o utilizador suportará os custos dos investimentos e todos os encargos de exploração e manutenção, bem como os custos ambientais e de oportunidade. Visa-se assim a equidade entre utilizadores e a internalização de custos ambientais por estes. O que também implica que um licenciamento imperfeito viola estes princípios, e particularmente o princípio da equidade que será um dos princípios fundamentais de uma sociedade democrática. Visto em termos puramente económicos, este é o princípio que melhor garante a eficiência das sociedades em termos globais. As suas implicações, da sua aplicação ou observância, ou não, são por isso enormes. Outro mérito da efectiva aplicação do PPP é o de dotar o Estado de verbas para o combate à poluição, desonerando assim os contribuintes em geral.

Os actos autorizativos ambientais deverão estar subordinados a planos e programas aprovados. Já é assim no Direito Nacional e assim deve continuar a ser. Os actos da administração têm de ser fundamentados no Direito e na boa técnica, reduzindo-se a margem de discricionaridade e a casuística. Tem ainda a ver com a racionalidade e a eficácia no uso de recursos que são por definição limitados, ainda que renováveis, e com a estratégia adoptada para a sua gestão. Justifica-se também tendo em conta a unidade do recurso (continuum naturale lhe chama a LBA).

Para ilustração da importância dos actos autorizativos ambientais na estratégia de combate à poluição cabe referir a legislação abundante publicada ao longo deste período relativa à protecção dos diferentes componentes ambientais naturais contra a poluição por substâncias perigosas. São classificadas nesta categoria substâncias muito diversas (metais pesados, insecticidas e pesticidas, compostos orgânicos, substâncias carcinogénicas e mutagénicas, etc), cuja presença nas águas, no ar ou no solo, onde em condições naturais não existem ou estão presentes em concentrações vestigiais, é susceptível de provocar danos significativos para a saúde humana ou para o ambiente, em particular para os seres vivos, substâncias essas cujas características próprias lhes conferem, por si só ou quando combinadas com outras substâncias, um elevado grau de persistência, toxicidade e bioacumulação. Como em condições naturais estas substâncias não estão presentes nos componentes ambientais naturais, são normalmente introduzidas, directa ou indirectamente, por descargas de águas residuais, por emissões para a atmosfera ou pela deposição de resíduos no solo. 
Para evitar os danos para a saúde humana e para o ambiente, torna-se necessário controlar as fontes de poluição pontual e difusa, por forma a assegurar que a concentração dessas substâncias no meio aquático e na atmosfera seja inferior a determinados limites, designados por objectivos de qualidade. Estes objectivos de qualidade são estabelecidos com base no melhor conhecimento científico disponível sobre a toxicidade dessas substâncias, aplicando factores de segurança definidos em função das suas características e dos seus efeitos sobre a saúde humana e sobre o ambiente. Aqueles objectivos de qualidade servem de referência para a definição dos programas de acompanhamento e vigilância para detecção da presença dessas substâncias no meio aquático e no ar e para a definição dos programas de medidas adequados para eliminar ou reduzir a poluição, sempre que os objectivos de qualidade sejam excedidos.

Como já foi dito, o mais poderoso mecanismo de combate à poluição por substâncias perigosas é o acto autorizativo ambiental. É no momento do licenciamento da actividade que a Administração pode impor limitações à actividade potencialmente poluente tendo em vista evitar o dano, promovendo a adopção de técnicas não poluentes em todos os sectores industriais que trabalham com, ou produzem, essas substâncias.

Essas limitações podem ser de vária natureza e o Direito do Ambiente tem já hoje ao seu dispor os VLE, os objectivos ou normas de qualidade para os componentes ambientais naturais, as disposições específicas sectoriais relativas ao licenciamento de descargas, os programas de acção aplicáveis aos diversos sectores de actividade industrial e à agricultura tendo em vista a redução ou a eliminação dessas substâncias (a proibição, no limite), e as melhores técnicas disponíveis e melhores práticas ambientais. São exemplo disto os Decretos-Lei n. ${ }^{\circ}$ 236/98, 52, 53, 54 e 431/99 e diversas portarias dessa época que fizeram a transposição das directivas relativas à protecção das águas contra a poluição por substâncias perigosas, a Portaria n. ${ }^{\circ}$ 286/93 que fixa valores guia e VLE para o ar e as emissões para a atmosfera, e o Decreto-Lei n. ${ }^{\circ}$ 506/99, de 20 de Novembro, que fixa os objectivos de qualidade para o meio aquático respeitante a determinadas substâncias perigosas.

Estas são normas vinculantes do acto autorizativo, determinadas em larga medida pelas ciências da engenharia e que, enquanto tal, conformam aqueles actos e reduzem a margem de discricionaridade da Administração. Neste sentido, viabilizam o controlo jurisdicional dos actos autorizativos ambientais (pelos tribunais nacionais e comunitário), preocupação que tem estado presente ao longo deste período no espírito do legislador comunitário e nacional, que promove, concomitantemente, um outro objectivo, esse não ambiental: o aperfeiçoamento das condições de concorrência no espaço comunitário. Essas regras exigem que todas as unidades que operam num determinado sector sejam sujeitas a idênticas condições de laboração no que concerne à internalização dos respectivos custos ambientais, o que é alcançado através da imposição de padrões de comportamento uniformes em todo o espaço comunitário no que respeita à prevenção da poluição. Porque esta questão transcende o espaço comunitário, assiste-se, na cena internacional, a um idêntico esforço normalizador que obedece às mesma razões ambientais (a poluição não conhece fronteiras devido ao continuum naturale) e económicas.

\section{LEIS RESERVA E INSTRUMENTOS DE GESTÃO DO TERRITÓRIO}

A LBA prevê, entre os instrumentos da política do Ambiente, o ordenamento integrado do território a nível regional e municipal, incluindo a classificação e criação de áreas, sítios ou paisagens protegidas sujeitos a estatutos especiais de conservação, a reserva agrícola nacional (RAN), a reserva ecológica nacional (REN) e os planos regionais de ordenamento do território, os planos directores municipais e outros instrumentos de intervenção urbanística. A orgânica do Ministério do Ambiente e Ordenamento do Território, aprovada pelo Decreto-Lei n. ${ }^{\circ}$ 120/2000, de 4 de Julho, veio a consagrar a integração do Ordenamento do Território na mesma tutela do Ambiente.

Temos pois que o Direito do Ambiente integra, por força das disposições da LBA, os instrumentos de planeamento do território entre os instrumentos da política ambiental, conferindo-lhes uma eficácia suplementar em vista à gestão do território. Por instrumentos de planeamento do território entendemos aqui as diferentes figuras previstas no artigo $2^{\circ}$ do Decreto-Lei n. ${ }^{\circ} 380 / 99$, de 22 de Setembro, que estabelece o regime jurídico dos instrumentos de gestão do território. Alguns destes instrumentos estão regulados por leis reserva surgidas durante este período.

Leis reserva são "leis que promovem a protecção de interesses posicionados a um nível superior, nacional, que, de um modo ou de outro, destacam ou reservam, do conjunto espacial representado pelo território nacional, um conjunto de áreas às quais pretendem proporcionar uma protecção especial mediante a imposição de vínculos de protecção ambiental incidente sobre os direitos de propriedade privada dos seus titulares, assumindo, por via destas características, em relação aos outros corpos normativos de prossecução ambiental, um valor reforçado" (in Moreira Fernandez, 2001). Ou seja, sobre esses espaços do território nacional integrados no objecto material de aplicação dessas leis, o exercício de direitos de propriedade privada é restringido, por força do vínculo ambiental assim criado, e as normas de protecção ambiental assumem um valor reforçado (um exemplo disto é dado pela norma do artigo $64^{\circ}$, n. $^{\circ} 8$, do Decreto-Lei n. ${ }^{\circ} 236 / 98$, que considera razões justificativas para a determinação de condições mais exigentes de descarga de águas residuais, entre outras, “o meio receptor estar situado em área designada para a protecção de habitats ou espécies relativamente às quais a conservação ou a melhoria da qualidade das águas seja um factor importante para a sua protecção, ou o meio receptor encontrarse classificado como REN").

Podem ser incluídas entre as leis reserva algumas das iniciativas legislativas mais originais e interessantes (e polémicas) surgidas no período em análise. É o caso do De- 
creto-Lei n. ${ }^{\circ}$ 196/98, de 14 de Junho, que estabelece o novo regime jurídico da RAN e revoga o anterior, que datava de 1982, e do Decreto-Lei n. ${ }^{\circ}$ 93/90, de 19 de Março, que revê o regime jurídico da REN estabelecido pelo Decreto-Lei n. ${ }^{\circ} 321 / 83$, de 5 de Julho, e o revoga.

A criação da RAN é justificada no preâmbulo do Decreto-Lei n. ${ }^{\circ}$ 196/98 pela necessidade de adopção de um regime jurídico que defenda de uma forma eficaz as áreas que, por serem constituídas por solos de maiores potencialidades agrícolas, ou por terem sido objecto de importantes investimentos destinados a aumentar a capacidade produtiva dos mesmos, se mostrem mais vocacionados para uma agricultura moderna e racional, no quadro da nossa inserção no espaço comunitário.

Os solos da RAN devem ser exclusivamente afectos à agricultura, sendo proibidas todas as acções que diminuam ou destruam as suas potencialidades agrícolas, designadamente as que consistam da construção de obras hidráulicas, vias de comunicação e acessos, construção de edifícios, aterros e escavações, lançamento ou depósito de resíduos, acções que provoquem erosão e degradação do solo, desprendimento de terras, encharcamento, inundações, excesso de salinidade e outros efeitos perniciosos e a utilização indevida de técnicas ou produtos fertilizantes e fitofarmacêuticos.

Carecem de prévio parecer favorável das comissões regionais da reserva agrícola todas as licenças, concessões, aprovações e autorizações administrativas relativas a utilizações não agrícolas de solos integrados na RAN. Os pareceres favoráveis das comissões regionais da reserva agrícola só podem ser concedidos em certas circunstâncias tipificadas na lei e quando não existam alternativas de localização em solos não incluídos na RAN ou, quando os haja, a sua implantação nestes inviabilize técnica e economicamente a construção.

No que concerne à REN, o Decreto-Lei n. ${ }^{\circ}$ 93/90, de 19 de Março, com as alterações que lhe foram introduzidas pelo Decreto-Lei n. ${ }^{\circ}$ 312/92, de 12 de Outubro, veio alterar o seu regime criado pelo Decreto-Lei n. ${ }^{\circ} 321 / 83$, de 5 de Julho. A REN foi criada com a finalidade de possibilitar a exploração dos recursos e a utilização do território com salvaguarda de determinadas funções e potencialidades, de que dependem o equilíbrio ecológico e a estrutura biofísica das regiões, bem como a permanência de muitos dos seus valores económicos, sociais e culturais. Integrando áreas indispensáveis à estabilidade ecológica do meio e à utilização racional dos recursos naturais, a REN constituía, assim, parte da rede fundamental de protecção das potencialidades biofísicas e culturais do território.

À semelhança do que acontece com a RAN, nas áreas incluídas na REN são proibidas as acções, de iniciativa pública ou privada, que se traduzam em operações de loteamento, obras de urbanização, construção de edifícios, obras hidráulicas, vias de comunicação, aterros, escavações e destruição do coberto vegetal. São áreas a considerar, para efeitos de integração na REN, as praias, dunas litorais primárias e secundárias, arribas ou falésias, uma faixa ao longo de toda a costa marítima até à batimétrica dos $30 \mathrm{~m}$, estuários, lagunas, lagoas costeiras e zonas húmidas adjacentes, ilhas, ilhéus e rochedos emersos do mar, sapais, restingas, tombo- los, leitos dos cursos de água e zonas ameaçadas pelas cheias, lagoas, suas margens naturais e zonas húmidas adjacentes, albufeiras, cabeceiras das linhas de água (em algumas situações), áreas de máxima infiltração, ínsuas, áreas com riscos de erosão e determinadas escarpas em função da geodinâmica e dimensão destes acidentes de terreno e do interesse cénico e geológico do local.

Leis reserva serão ainda os diferentes diplomas regulamentares previstos no Decreto-Lei n. ${ }^{\circ}$ 19/93, de 23 de Janeiro, que estabelece as normas relativas à Rede Nacional de Áreas Protegidas (RNAP). O diploma identifica, como objectivos de interesse público a prosseguir mediante a implementação e regulamentação de um sistema nacional de áreas protegidas, nas quais condiciona as intervenções artificiais susceptíveis de as degradar, a conservação da natureza, a protecção dos espaços naturais e das paisagens, a preservação das espécies da fauna e da flora e dos seus habitats naturais, a manutenção dos equilíbrios ecológicos e a protecção dos recursos naturais contra todas as formas de degradação.

A classificação de áreas protegidas visa a preservação das espécies animais e vegetais e dos habitats naturais que apresentem características peculiares, quer pela sua raridade e valor científico, quer por se encontrarem em vias de extinção, a reconstituição das populações animais e vegetais e a recuperação dos habitats naturais das respectivas espécies, a preservação de biótopos e de formações geológicas, geomorfológicas ou espeleológicas notáveis, a preservação ou recuperação dos habitats da fauna migratória, a protecção e a valorização das paisagens que, pela sua diversidade e harmonia, apresentem interesses cénicos e estéticos dignos de protecção, e o estabelecimento de reservas genéticas, garantindo a perenidade de todo o potencial genético, animal e vegetal, entre outros objectivos fixados no diploma. A estes acresce o objectivo da promoção do desenvolvimento sustentado da região, valorizando a interacção entre os componentes ambientais naturais e humanas e promovendo a qualidade de vida das populações e a valorização de actividades culturais e económicas tradicionais, assente na protecção e gestão racional do património natural.

O decreto regulamentar de classificação de uma área protegida pode fixar condicionamentos ao uso, ocupação e transformação do solo, bem como interditar, ou condicionar a autorização dos respectivos órgãos directivos no interior da área protegida, as acções e actividades susceptíveis de prejudicar o desenvolvimento natural da fauna ou da flora ou as características da área protegida (nomeadamente a introdução de espécies animais ou vegetais exóticas, as quais, quando destinadas a fins agro-pecuários, devem ser expressamente identificadas), as actividades agrícolas, florestais, industriais, mineiras, comerciais ou publicitárias, a execução de obras ou empreendimentos públicos ou privados, a extracção de materiais inertes, a utilização das águas, a circulação de pessoas e bens e o sobrevoo de aeronaves.

Ao contrário do que prevê a Lei n. ${ }^{\circ}$ 13/85, de 6 de Julho, relativa à protecção do património artístico, histórico e cultural construído, a legislação sobre a RNAP não prevê, para os particulares afectados, o direito de oposição 
à classificação com a consequente expropriação do imóvel afectado e pagamento de justa indemnização, ao contrário do que acontece noutros países (em França, por exemplo). Apenas a reserva total dará lugar à expropriação dos terrenos abrangidos pela medida.

Trata-se, como se evidencia, em qualquer dos casos, de condicionantes particularmente severas e susceptíveis de afectarem direitos económicos dos particulares.

Estabelecidas as bases da política de ordenamento do território e de urbanismo pela Lei n. ${ }^{\circ} 48 / 98$, de 11 de Agosto, o Decreto-Lei n. ${ }^{\circ} 380 / 99$, de 22 de Setembro, veio desenvolver as bases da política de ordenamento do território e de urbanismo, definindo o regime de coordenação dos âmbitos nacional, regional e municipal do sistema de gestão territorial, o regime geral de uso do solo e o regime de elaboração, aprovação, execução e avaliação dos instrumentos de gestão territorial.

De acordo com o preâmbulo daquele diploma, a política de ordenamento do território e de urbanismo assenta no sistema de gestão territorial que se organiza, num quadro de interacção coordenada, em três âmbitos: nacional, regional e municipal. O âmbito nacional é concretizado através do programa nacional da política de ordenamento do território, dos planos sectoriais com incidência territorial e dos planos especiais de ordenamento do território, compreendendo os planos de ordenamento de áreas protegidas, os planos de ordenamento de albufeiras de águas públicas (POAAP) e os planos de ordenamento da orla costeira (POOC).

Quanto à vinculação jurídica, aspecto essencial deste Direito, apenas os planos municipais de ordenamento do território e os planos especiais de ordenamento do território, entre os quais se contam os POOC e os POAAP, vinculam as entidades públicas e ainda, directa e imediatamente, os particulares, todos os demais planos vinculando apenas as entidades públicas.

A elaboração e aprovação dos POOC são regulamentadas pelo Decreto-Lei n. ${ }^{\circ}$ 309/93, de 2 de Setembro, mas os princípios a que deve obedecer a ocupação, o uso e a transformação da faixa costeira, assim como a protecção e a revalorização do litoral ficaram estabelecidos pelo Decreto-Lei n. ${ }^{\circ} 302 / 90$, de 26 de Setembro. O ponto de partida do legislador foi a preocupação com a protecção da orla costeira da pressão a que se encontra sujeita devido ao seu elevado valor cénico e ambiental. A vocação dos POOC é a definição de critérios para o licenciamento das utilizações dos terrenos do domínio público marítimo e o ordenamento da ocupação das faixas de protecção.

O Decreto-Lei n. ${ }^{\circ} 309 / 93$, viria a ser alterado e regulamentado pelo Decreto-Lei n. ${ }^{\circ}$ 218/94, de 20 de Agosto, que veio determinar para estes planos a natureza de regulamentos administrativos, sujeitando-os a aprovação por resolução do Conselho de Ministros. Simultaneamente veio regulamentar o título de licença ou concessão e determinar que, pelo uso privativo de terrenos dominiais, é devida uma taxa anual cujo produto reverte em partes iguais para o INAG e para as DRARN. Como contrapartida da concessão é devido um preço a fixar pelo INAG, ponderada a média dos montantes dos preços fixados em concursos abertos no último ano para idênticos efeitos.

A criação de numerosas albufeiras de águas públicas destinadas à rega, à produção de energia hidroeléctrica e ao abastecimento de populações, propiciou que se reunissem condições para a prática de actividades recreativas e a construção, nos terrenos circundantes, de casas de veraneio, parques de campismo e estabelecimentos hoteleiros. Tornou-se, assim, necessário subordinar o exercício das actividades secundárias, proporcionadas pelas albufeiras de águas públicas, às finalidades primordiais da sua criação, conciliando-as tendo em conta os diversos interesses em presença. Essa preocupação motivou a publicação do Decreto-Lei n. ${ }^{\circ}$ 502/71, de 18 de Novembro, visando a classificação das albufeiras de águas públicas, o estabelecimento de adequadas zonas de protecção, com o correspondente ordenamento territorial, e a regulamentação do exercício das actividades compreendidas no aproveitamento secundário das albufeiras. O Decreto Regulamentar n. ${ }^{\circ}$ 2/88, de 20 de Janeiro, veio classificar, para efeitos da aplicação do Decreto-Lei n. ${ }^{\circ}$ 502/71, as albufeiras de águas públicas de serviço público e regulamentar aquele diploma.

Nas zonas de protecção das albufeiras de águas públicas classificadas fica proibido todo um conjunto de actividades e instalações potencialmente tóxicas e poluentes. O diploma prevê que cada albufeira classificada será objecto de um ordenamento territorial da respectiva zona de protecção, no qual serão especificados os locais de proibição ou de condicionamento da construção habitacional, industrial ou recreativa. A obrigatoriedade da elaboração e aprovação de um plano de ordenamento para cada albufeira de águas públicas veio a ser estatuído pelo Decreto Regulamentar n. ${ }^{\circ} 37 / 91$, de 23 de Julho, em condições claramente inspiradas pelas normas do Decreto-Lei n. ${ }^{\circ}$ 218/94 relativo aos POOC.

Outro instrumento de protecção, agora para as águas subterrâneas destinadas ao abastecimento público, é o Decreto-Lei no 382/99, de 22 de Setembro, que estabelece as normas e os critérios para a delimitação de perímetros de protecção das captações e condiciona as actividades nos terrenos assim delimitados. Mais uma vez, são criadas servidões em razão de objectivos de protecção da qualidade das águas.

\section{TENDÊNCIAS ACTUAIS DE DESENVOLVIMENTO DO DIREITO DO AMBIENTE}

O Direito do Ambiente sofreu uma evolução estonteante ao longo dos 25 anos em análise. Essa evolução prossegue enquadrada por um novo paradigma. Se, até aqui, a preocupação central do Direito do Ambiente podia ser traduzida pelos princípios da precaução (in dubio pro natura) e da prevenção (mais vale prevenir do que remediar), qualquer um deles vocacionado primariamente para a protecção do ambiente, o novo paradigma sobre o qual vêm sendo construídas as mais recentes peças do Direito 
Comunitário do Ambiente parte do conceito da responsabilidade da presente geração na reparação do dano causado ao ambiente. Ou seja, considerando o estado de degradação a que o ambiente chegou, a responsabilidade intergeracional deve ir mais longe, no sentido da restauração da qualidade do ambiente, aproximando-a do seu estado pristino, preservando tanto a variedade como a abundância e a própria qualidade ou estado de conservação dos bens ambientais. Este é o novo paradigma da directiva quadro da água, do Protocolo de Quioto à Convenção Quadro das Alterações Climáticas, da directiva 96/61/CE sobre a prevenção e controlo integrados da poluição (dita directiva IPPC, transposta para o Direito interno pelo Decreto-Lei n. ${ }^{\circ}$ 194/2000, de 21 de Agosto), da directiva 96/62/CE relativa à avaliação e gestão da qualidade do ar ambiente (transposta pelo Decreto-Lei n. ${ }^{\circ}$ 276/99, de 23 de Julho) e do $6^{\circ}$ Programa da Comunidade Europeia de Política e Acção em Matéria de Ambiente e Desenvolvimento Sustentável, nomeadamente.

Este novo paradigma constrói-se sobre alguns princípios já conhecidos e é operacionalizado através do recurso a alguns conceitos e instrumentos inovadores e outros que, sem o serem, pela sua adopção sistemática, em si mesma inovadora, confluem com os primeiros para a definição de uma nova política.

São os seguintes os pilares da estratégia de ataque aos problemas ambientais que responde às necessidades do novo paradigma: (1) a gestão ambiental em função de objectivos de recuperação do bom estado dos diferentes componentes ambientais naturais; (2) integração das medidas destinadas à protecção e melhoria do estado de qualidade dos componentes ambientais em programas devidamente calendarizados; (3) adopção de tecnologias limpas (as melhores técnicas e melhores práticas ambientais disponíveis); (4) abordagem integrada da protecção dos vários componentes ambientais naturais; (5) integração da política de Ambiente nas políticas sectoriais; (6) contratualização; (7) recuperação de custos; (8) instrumentos financeiros, fiscais e de mercado e; (9) generalização da informação e consulta do público.

A gestão ambiental em função de objectivos de recuperação do bom estado dos diferentes componentes ambientais naturais é uma exigência que decorre do artigo $174^{\circ}$ do Tratado da UE. É aí claramente identificado, como objectivo para a política comunitária no âmbito do Ambiente, a contribuição para a prossecução dos objectivos de preservação, protecção e melhoria da qualidade do ambiente. A gestão ambiental em função de objectivos de qualidade integra já o Direito do Ambiente nacional desde pelo menos a LBA, de 1987. Que esses objectivos sejam agora uns de recuperação da qualidade dos componentes ambientais é inovador, tal como o é que esses objectivos devam ser considerados como condicionantes no licenciamento das actividades potencialmente poluidoras e na renovação dessas licenças, sempre que a sua consideração determine a necessidade de medidas mais restritivas do que aquelas que seriam justificadas à luz dos critérios de protecção do ambiente que são definidos por considerações da concorrên- cia, como é o caso dos VLE e das melhores técnicas disponíveis da legislação sectorial para a protecção do ar ambiente, das águas e do solo. É esta a essência do conceito de abordagem combinada introduzido no Direito Comunitário pelo artigo $10^{\circ}$ da directiva IPPC.

Este conceito estava já presente no artigo $64^{\circ}$ do Decreto-Lei n. ${ }^{\circ}$ 236/98, normas de qualidade das águas, e na legislação relativa às descargas de águas residuais urbanas (Decreto-Lei n. ${ }^{\circ}$ 152/97, de 19 de Junho) que define um calendário de realização de sistemas de recolha e tratamento e prevê normas de descarga mais ou menos exigentes consoante a dimensão do aglomerado (que nos dá a medida do impacte que pode ser esperado sobre o meio receptor) e o estado de qualidade do meio receptor e sua capacidade de autodepuração (através da classificação destes em zonas sensíveis, zonas normais e zonas menos sensíveis). Está também presente no diploma relativo à protecção das águas contra a poluição por nitratos de origem agrícola, o Decreto-Lei n. ${ }^{\circ}$ 235/97, de 3 de Setembro, que determina a necessidade de programas de medidas e a adopção de boas práticas agrícolas quando justificado pelo estado de degradação da qualidade das águas subterrâneas (zonas vulneráveis) tendo em vista a recuperação da sua qualidade. A DQA virá generalizar a abordagem combinada a vários outros domínios.

Quanto aos programas de medidas, eles são, já hoje, elemento fundamental da política nacional e comunitária de Ambiente e têm consagração na LBA. No que respeita à água, o Decreto-Lei n. ${ }^{\circ}$ 45/94, de 22 de Fevereiro, é disso exemplo. Os planos de bacia hidrográfica e o Plano Nacional da Água recentemente aprovados são planos sectoriais para efeitos da estratégia nacional de gestão do território. Mas não são os únicos planos e programas aprovados nos anos mais recentes. Outros exemplos importantes são o Plano Estratégico de Gestão de Resíduos Industriais, aprovado pelo Decreto-Lei n. ${ }^{\circ}$ 516/99, de 2 de Dezembro, o Plano Estratégico dos Resíduos Sólidos Urbanos, de 1997, o Plano Nacional de Prevenção de Resíduos Industriais, o Plano Estratégico dos Resíduos Hospitalares e o Programa Nacional para as Alterações Climáticas.

Muitos destes planos e programas não têm caracter vinculante, carecendo de força de lei. Outros mais não representam do que obrigações de diligência impostas à Administração. O que há de inovador na nova geração de programas de medidas e de planos é que eles estão destinados a criar obrigações de resultados à Administração, que não poderá então omitir-se, como sucede com demasiada frequência, sem consequências para o Estado-membro. Os programas de medidas da DQA ficam a meio caminho, uma vez que não criam explicitamente uma obrigação de resultados mas a sua avaliação a meio do prazo de execução e a revisão que terá lugar caso se constate que os objectivos fixados não estão em vias de ser alcançados, constituem uma aproximação a esse conceito.

A adopção de tecnologias limpas está consagrada em vários diplomas recentes, com destaque para o Decreto-Lei n. ${ }^{\circ} 194 / 2000$, que transpõe para a ordem jurídica interna a directiva IPPC, e visa a redução da poluição produzida em 
alternativa aos sistemas de tratamento ditos de "fim de linha". Aquele diploma cria uma Comissão Consultiva para a Prevenção e Controlo Integrado da Poluição à qual atribui a competência para a análise das melhores técnicas disponíveis, por sector de actividade, que servem de referência, em termos nacionais, para efeitos da emissão da licença ambiental. $\mathrm{Na}$ acepção deste diploma, melhores técnicas disponiveis são "a fase de desenvolvimento mais avançada e eficaz das actividades e dos respectivos modos de exploração, que demonstre a aptidão prática de técnicas específicas para constituir, em princípio, a base dos valores limite de emissão com vista a evitar e, quando tal não seja possível, a reduzir de um modo geral as emissões e o impacte no ambiente no seu todo", entendendo-se por disponiveis "as técnicas desenvolvidas a uma escala que possibilite a sua aplicação no contexto do sector industrial em causa em condições económica e tecnicamente viáveis, tendo em conta os custos e os benefícios, quer essas técnicas sejam ou não utilizadas ou produzidas a nível nacional ou comunitário, desde que sejam acessíveis ao operador em condições razoáveis". Os próprios termos destas definições evidenciam as preocupações de natureza económica que estão subjacentes a este conceito.

A abordagem integrada é hoje uma das traves mestras de toda a política do Ambiente da UE e portuguesa, na linha do Quinto Programa Comunitário de Acção em Matéria de Ambiente e Desenvolvimento Sustentável, de que a publicação da directiva IPPC, constitui a concretização. Esta directiva, reconhecendo que a existência de abordagens diferentes no controlo da poluição do ar, das águas e do solo pode favorecer a transferência dos problemas de poluição entre os meios físicos, em vez de favorecer a protecção do ambiente no seu todo, assume, como escopo essencial, o objectivo de uma abordagem integrada do controlo da poluição, assente prioritariamente na prevenção, sempre que possível, das emissões para o ar, a água e o solo, ou na correspondente minimização dessas emissões, como meio de alcançar um nível elevado de protecção do ambiente no seu todo.

Estes não são, no entanto, os únicos aspectos a considerar quando falamos de integração em relação com a protecção do ambiente, pois temos também que considerar a integração das políticas ambientais com as políticas agrícola, energética, de ordenamento do território, industriais (em sentido mais lato), do turismo e lazer, obrigação já inscrita na CRP e no Tratado da União. Nas palavras de Gomes Canotilho et al. (1998) "traduz a ideia de que a protecção do ambiente deve ser uma preocupação subjacente a todas as actividades". A adopção recente de uma directiva que sujeita a avaliação de impactes ambientais os planos e programas, reforça este eixo da estratégia comunitária para o Ambiente.

Quanto à contratualização das medidas de protecção do ambiente, já hoje estão previstas na legislação nacional, nomeadamente nos artigos $68^{\circ}$ e $78^{\circ}$ do Decreto-Lei n. ${ }^{\circ}$ 236/98, as figuras dos contratos de adaptação ambiental e de promoção ambiental, respectivamente, os primeiros destinados a criar condições para a adaptação das instala- ções às condições ambientais mais exigentes criadas pela legislação, os segundos destinados à adopção voluntária, pelas instalações, de padrões ambientais mais exigentes do que os legislados. O seu sucesso não tem sido evidente, mas serão seguramente instrumentos importantes da política de Ambiente do futuro.

O princípio da recuperação de custos aplica-se aos serviços de águas e foi introduzido pela DQA. Pretendese com isto que as políticas de preços da água dêem incentivos adequados para que os consumidores utilizem eficientemente a água, e assim contribuam para os objectivos ambientais da directiva, e que seja estabelecido um contributo adequado dos diversos sectores utilizadores para a recuperação dos custos dos serviços de abastecimento de água, baseado numa análise económica e que tenha em conta o princípio do poluidor-pagador e do utilizador-pagador e que atenda, nomeadamente, às consequências sociais, ambientais e económicas desta política de recuperação de custos. À semelhança de outros diplomas para outros componentes ambientais referidos, a directiva-quadro estabelece objectivos exigentes de qualidade da água e estipula que a aplicação das políticas de preços da água não pode constituir motivo para o incumprimento desses objectivos. Assim, por aplicação de instrumentos normativos e medidas administrativas, todos os custos, incluindo as externalidades ambientais e os custos de escassez, deverão ser transferidos progressivamente para os utilizadores dos serviços da água através das respectivas tarifas.

Quanto aos instrumentos financeiros e fiscais, para além das taxas ambientais, cuja implementação entre nós tarda, haverá a considerar os impostos ambientais, que incidirão sobre as actividades poluentes, mas cuja introdução suscita várias questões de natureza económica em relação com a competitividade dos nossos produtos nos mercados comunitários e terceiros onde eles não existem.

Quanto aos mercados de emissões e da água, já em vigor noutras paragens, serão instrumentos importantes para a determinação dos custos de oportunidade e de escassez e para a introdução de alguma racionalidade económica na relação das empresas com o Ambiente.

A generalização da informação e consulta do público é um dos pilares da estratégia comunitária para o Ambiente. Não é já o direito à informação que está em causa, mas a colaboração do público na verificação da conformidade dos actos administrativos e das práticas das diferentes instituições com competências e interesses ou cujas actividades possam ter impactes no ambiente.

Como foi já referido, a Lei n. ${ }^{\circ} 83 / 95$ consagra o direito de participação procedimental e de acção popular. São interesses protegidos pela referida lei, entre outros, a saúde pública, o ambiente, a qualidade de vida e o domínio público, sendo titulares destes direitos quaisquer cidadãos no gozo dos seus direitos civis e políticos e as associações e fundações defensoras desses interesses, independentemente de terem ou não interesse directo na demanda. Encontra-se entretanto em preparação uma proposta de directiva sobre esta matéria que visa harmonizar a legisla- 
ção comunitária com as disposições da Convenção de Aarhus, sobre acesso às informações, a participação do público e o acesso à justiça no domínio do Ambiente. Esta proposta tem um duplo objectivo: por um lado, garantir o acesso às informações sobre ambiente mantidas pelas autoridades públicas e estabelecer condições básicas do seu exercício, por outro lado, garantir igualmente que as informações sobre ambiente sejam, por princípio, disponibilizadas e divulgadas junto do público, nomeadamente através das tecnologias telemáticas e electrónicas disponíveis.

\section{CONCLUSÃO}

Tratámos anteriormente das leis, regulamentos, princípios e conceitos do Direito do Ambiente. Não tratámos do regime de contraordenações, por falta de tempo (o leitor interessado poderá consultar Leones Dantas, 2001, no que toca a esta matéria). Por manifesta falta de espaço não aprofundámos a análise em tantos outros domínios. Incidentalmente abordámos questões relativas à aplicação do Direito, ou à falta dela. Estas são, no entanto, questões maiores quando se olha para o Direito do Ambiente numa perspectiva não académica, interventora, que é aquela em que nos colocamos.

As obrigações criadas pelas novas disposições do Direito do Ambiente aos organismos da Administração do Ambiente não cessam de crescer, e as suas consequências sobre os interesses legítimos dos particulares são cada dia mais pesadas. A forma ligeira como muitas destas questões têm sido tratadas e como algumas soluções têm sido elaboradas, sem consideração por estes aspectos, leva a uma situação de déficit generalizado da aplicação deste Direito que não será isenta de consequências, tanto do ponto de vista ambiental como económico e social. Portugal, enquanto Estado-membro da EU não deixará de ser penalizado severamente pelas suas omissões nesta matéria.

\section{REFERÊNCIAS}

AMADO GOMES, C. (2000). A Prevenção à Prova no Direito do Ambiente, em Especial, os Actos Autorizativos Ambientais. Coimbra Editora.

FIGUEIREDO DIAS, J. E. O. (2002). Direito Constitucional e Administrativo do Ambiente. Cadernos CEDOUA, Almedina.

FREITAS do AMARAL, D. (1994). "Apresentação" in Direito do Ambiente. INA.

GOMES CANOTILHO, J. J., CLÁUDIA M. C. SANTOS, JOSÉ E. O. F. DIAS e M. ALEXANDRA S. ARAGÃO (1998). Introdução ao Direito do Ambiente. Universidade Aberta.

LEONES DANTAS, A. (2001). Contra-ordenações Ambientais. Descargas de Águas Residuais. Revista do Ministério Público, n. ${ }^{\circ} 86$ e 87.

MOREIRA FERNANDEZ, M. ELIZABETH (2001). O Direito ao Ambiente e Propriedade Privada. Studia Iuridica 57, Coimbra Editora.

SANTOS MAÇÃS, M. FERNANDA (1996). A Suspensão Judicial dos Actos Administrativos e a Garantia Constitucional da Tutela Judicial Efectiva. Studia Iuridica 22, Coimbra Editora.

SOUSA FRANCO, A. (1994). "Ambiente e Desenvolvimento" in Textos. Ambiente. Centro de Estudos Judiciários, pg. 268 e 269.

\section{The Evolution of Portuguese Environmental Law During the Past 25 Years}

\section{ABSTRACT}

During the last 25 years, Environmental Law has undergone a revolution in Portugal. The right to a healthy Environment was recognized as a civil right by the Constitution of 1976, which entitles it to legal protection equivalent to that ensured to other civil rights. As a consequence, a new branch of Law was born, Environmental Law. The most important moments and laws approved during this period are reviewed and discussed, and their contribution to the general objective of protection of the Environment is assessed

Key Words: Portugal; environmental; legislation. 